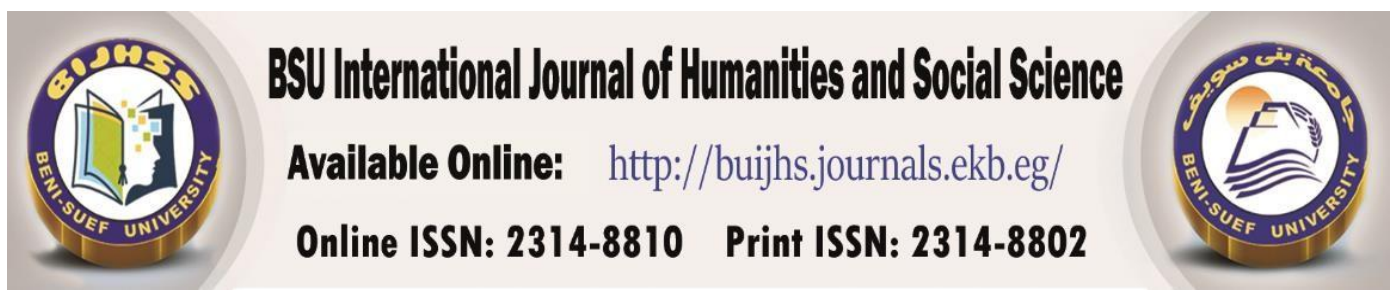

\title{
Textuality and Ambiguity of Forensic Texts \\ Egyptian Supreme Court: A Model
}

\section{Dr. Fakhry Muhammad Al-Sayed Elieba*}

\author{
E-MaiL: alsun 2012@hotmail.com
}

\section{ABSTRACT}

Legal language is an arcane and often impenetrable category. This present study aims to describe the legal texts field and distinguish between its various aspects, in addition to exploring the distinctive field of homicide investigations at the Egyptian Supreme Court in-depth. Therefore, this paper is supported by three cases from the

ARTICLE INFO

Received

2020-09-02

Accepted

2020-12-09

Keywords

Textuality,

Ambiguity,

LegalTexts,

Forensic

Linguistics,

linguistic

fingerprint.

* Department of English, Gulf Colleges, Kingdom of Saudi Arabia considering both the characteristics and criteria of forensic linguistics, linking text to context, and providing types of ambiguity either lexical or structural. In a meaningful text, the combination of textuality and ambiguity can contribute to its cohesion and coherence. Textual analysis of these legal texts also involves understanding forensic language to gain information and providing cues to ways through which communication of social structures is understood. Textual analysis in legal studies, like other texts, operates at seven criteria of text. In addition to paying particular attention to specific lexical and structural ambiguity in forensic texts of cases under investigation. This paper aims to examine the textuality features and thematic structures embedded in the Egyptian Supreme legal texts, and to determine the most dominant causal factors of ambiguities in the Egyptian Supreme legal texts. There are many consequences that can be drawn from these properties in terms of research techniques used to extrapolate the nature of legal texts. These techniques are used to extrapolate the relationships between textuality and ambiguity. There are three criminal cases in this paper that contain either lexical or structural ambiguity. 
Elieba, Fakhry Muhammad Al-Sayed. (BIJHS) 2020, 2 (2): 114 - 164 


\section{Introduction}

The purpose of this paper is to demonstrate the use of forensic linguistics through three cases of the Egyptian Supreme Court from the field of forensic linguistics. In Olsson's (2004) statement, forensic linguistics can be defined as "the application of linguistics to legal issues" (p.1). In this field, the goal is to understand the different ways where language and law are intertwined. As a text, forensics has often been described as a form of social analysis, based on the emphasis on 'message'. This is informed by focusing on utterances and paying attention to what is being done. Studying Egyptian legal texts involves examining text types and forms of analysis in criminal contexts and examining some forms of ambiguity. Forensic linguistics may be traced back as early as $(1927)^{(1)}$. According to Olsson (2008),

The term forensic linguistics was coined by Svartvik in (1968) to analyze the statements of homicide victims. In the 1980s, some specialists discussed how linguistics could be applied to legal cases. Since the 2000s, forensic linguistics has undergone a significant growth that has been characterized as a coming-of-age (2). According to Olsson (2004), forensic linguistics examines language as it is used by a judge, during cross-examination, evidence presentation, police cautions, police testimonies and the questioning process in court. The following types of legal texts are enumerated by some scholars:

1. (Olsson, 2008) Identification of emergency calls based on linguistic information in threatening situations. 2. Threats relating to ransom demands or other threats identified as genuine or false (Falzini, 2008). 3. A suicide note that is short, concise, and highly propositional with some degree of equivocation (Olsson, 2004), 4. In death row statements, either the crime is admitted or denied. 5. A virtual authorship attribution case analyzes social media statements in order to determine whether they are illegal (as in prostitution or drug trafficking), or unethical (as in coercion or violence). 6. The argument of intellectual property and trademarks (Hardaker, 2015). 7. Disputes regarding author identification, that is, the 
determination of who wrote anonymous texts like threat letters, mobile phone texts, emails, plagiarism, voice recognition, etc. 8 . In linguistics, a fingerprint consists of symbols that identify a speaker/writer as a unique individual. 9. In fact, this field can even analyze the black boxes of airplanes ${ }^{(3)}$. A legal text has to be precise and inclusive in order to be taken seriously (Gibbons, 2004).

Because there are inherent dangers involved with editing a simpler text because it loses something in analysis, some knowledge of the legal determinants of activity is therefore necessary. Crystal (2003) notes that legal discourse has a wide range of directions. Despite the fact that its statements have to be phrased in such a way that we can consider their general applicability, they must still be specific enough to apply to individual situations... Above all, they have to be expressed in such a way that people can be certain about the intention of the law respecting their rights and duties (p. 374)." Therefore, analysis of textuality integrated with ambiguity in the field of forensics are important. Based on the explanation above, this paper aims to analyze the words, phrases or/and sentences that contain ambiguities found in Supreme Appeal No. 10017 of judicial 88, Supreme Appeal No. 17730 of judicial 88, Supreme Appeal No. 11229 of judicial 88. Furthermore, the causal factors of each ambiguity are also explained in this study.

\section{Literature Review}

Shuy, R. W. (2001) explores the defining characteristics of discourse analysis in legal contexts. This study explains how Forensic Linguistics is a relatively newly recognized field of study, but has progressed with great general collections of articles on language and law, including (Gibbons, 1994; Levi and Walker, 1990; Rieber and Stewart, 1990), books describing the language of the courtroom (Solan, 1993; Stygall, 1994), bilingualism in the courtroom (Berk-Seligson, 1990), and aircraft communication breakdowns (Cushing, 1984). In this study, it examines the use of familiar tools for analyzing criminal cases, such as topic and response analyses, speech act analysis, and pragmatic analysis, as central to the evidence used in criminal proceedings, voice identification, and defamation claims based on libel and slander 
charges. A final part of the study deals with both written and spoken discourse analysis, as well as ambiguity in language.

Ali, J (2020) identifies a paper in criminal forensic linguistics. This paper discusses the important contributions of forensic linguistics in the field of law. The paper provides a brief overview of Forensic Linguistics (FL) in comparison with phonetics, syntax, and other branches of linguistics. Law and linguistics are blended together in this approach. This is an interdisciplinary approach since it relies on other disciplines such as syntax, semantics, pragmatics, discourse analysis, critical discourse analysis, stylistics, and phonology. Furthermore, the paper examines the development, importance, and applications of forensic linguistics. This study correlates forensic linguistics with language crimes, including defamation, bribery, perjury, conspiracy, solicitation, plagiarism, and threatening crimes committed through language. As a result of its high importance for legal proceedings, forensic linguistics is expected to be an exciting field in the future

Zakaryiah, L. (2013) presents a study on 'Textuality as a Linguistic Mechanism for Codifying Legal Maxims in Islamic Criminal Law'. This study examines the use of textuality as a linguistic mechanism to codify legal maxims derived from Qur'anic exegesis. In addition to textuality, other approaches such as intertextuality and hypertextuality can also be applied. In these linguistic notions, part of the internal structure of texts is described, along with how utterances relate to one another and are interconnected in a coherent way between different texts. Finally, this study concludes that the codification of legal maxims from texts can be done directly or indirectly.

Olsson (2008) discusses forensic phonetics and its text types to shed light on applied linguistics of forensic science. He also investigates conditions of authorship in police interviews, judges and juries and the meaning of legal words. This study presents a brief demonstration of author profiling by emphasizing some presentational elements. However, it emphasizes the fact that the analysis does not deal with psychology or personality profiling, topics about which the author expresses no opinion. In this study, 
several techniques of statements are investigated, whether oral or written, uninterrupted or in interview form. Several categories under which statements could be analyzed have been given. As pointed out, there are many other categories, and some of these were illustrated as raw materials for statement analysis.

Salih, A. H. (2015) presents a contrastive study of structural ambiguity in English and Arabic. It refers to significant aspects of sentence structure both in English and Arabic. The study points out that there are several factors causing structural ambiguity. These factors include the duality of parts of speech, absence of functional words, immediate constituent, compound, and grammatical words... etc. Contrastive analysis has been conducted to identify the points of similarities and differences between the factors of structural ambiguity in the two languages. It tackles types of ambiguity, factors of structural ambiguity, location of ambiguity and situations of grammatical ambiguity in the language.

\section{Research Methodology}

This study aims to analyze both the textuality and ambiguity of Egyptian legal texts. The data comes from the Egyptian Supreme Court. Retrieved from https://www.cc.gov.eg/criminal_judgments. There are three cases consecutively as follows: Supreme Appeal ( No. 10017)of judicial (88), Supreme Appeal (No. 17730) of judicial (88), Supreme Appeal (No. 11229) of judicial (88). Each of the three Supreme appeals contains textual or ambiguous meanings, which will need to be analyzed. Method of data analysis depends on: a. Features of textuality, b. Identifying possible ambiguous words, phrases, and sentences, and c. Classifying them into types of ambiguity such as lexical or structural ambiguity.

\section{Objectives of the Study}

The objectives of this paper are intended to achieve the following:

1. To identify the characteristics of the Egyptian Supreme legal texts.

2. To analyze the textual features and thematic structures imbued in the Egyptian Supreme legal texts.

3. To determine the most dominant causal factors of ambiguities in 
the Egyptian Supreme legal texts.

4. To highlight the phenomena generating ambiguities that can be resolved by specific mechanisms.

\section{Problems of the Study}

1. What are the characteristics of the Egyptian Supreme forensic texts?

2. What are the nature of the textual features and thematic structures imbued in the Egyptian Supreme legal texts?

3. To what extent are the causal factors of lexical and structural ambiguities detected in the Egyptian legal language?

4. How can the phenomena that generate ambiguities be resolved by specific mechanisms?

\section{Significance of the Study}

The results of this study provide some mechanisms for understanding textuality and ambiguity in Egyptian Supreme legal texts. In addition, this study contributes to the theoretical and practical fields of forensic linguistics. In the theoretical field, it will provide knowledge of the Egyptian forensic textuality, as well as how to disambiguate intended meanings either lexically or structurally in the Egyptian legal texts. Practically, it gives some information about the textual features of legal texts and types of ambiguity used in dealing with the Supreme court of Egypt.

\section{7- Discussion and Analysis}

\subsection{Characteristics of Legal language}

In this paper, some of the main linguistic features of Egyptian Supreme legal texts are discussed. There are also some lexical features in these legal texts. Legal texts can be distinguished by five characteristics, as outlined by Cornu (1990):

1. Legal language is a special language in all countries of the world. Therefore, legal vocabulary is a set of terminological terms that have special meanings in legal discourse (p.22). 
2. Legal language is a specialized language that legislators, judges, and attorneys use (p. 23).

In the opinion of Tiersma (1999), if a word or phrase is exclusively used by a certain profession, or if it is interpreted differently from its normal meaning, and the term has a relatively well-defined meaning, it should be considered a technical term. In the table (1) below, some technical terms are displayed as they are being used in the Egyptian Supreme legal texts:

\begin{tabular}{|c|c|}
\hline English language & Arabic language \\
\hline action immune to the stigmatization & 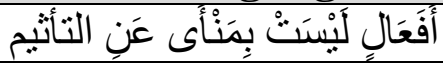 \\
\hline decree & 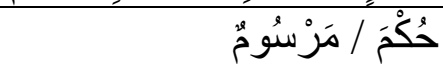 \\
\hline deem & يَعْنَتَرُ وَيَعُدْ \\
\hline appeal & 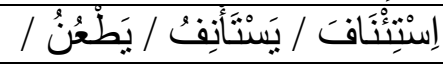 \\
\hline autopsy & تََْْرِيحَ جَرِيمَةِة \\
\hline coroner & 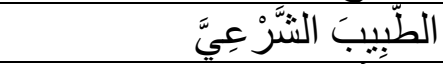 \\
\hline felony & جِنَابَةُ \\
\hline misappropriation of public funds & 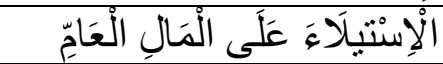 \\
\hline abuse of authority & 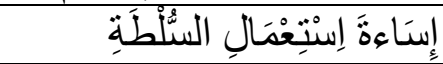 \\
\hline influence peddling & 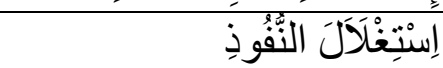 \\
\hline a permanent ( irreversible) disability & 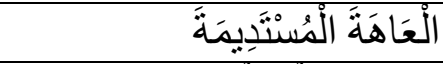 \\
\hline abduction / kidnapping & عَمَلِيَاتِ الْخَطْفِ \\
\hline homicide & جَرِيََة قَتَلٍْ \\
\hline hostage-taking & أَخَذَ الرَّ هَائئنُ \\
\hline bribery & الرََّثْوَةًَ \\
\hline embezzlement & الإخْتِتَلَسِ \\
\hline rape & الِْغِتِصَابَ \\
\hline armed (compulsive) robbery & السَّرِقَةًَ بِالْإِكْرَ اهِ \\
\hline drug trafficking & الْمُخَدِّرَاتِ \\
\hline terrorism & الإر هَابْ \\
\hline profiteering & التنَّرَبُّحَ \\
\hline
\end{tabular}

Table (1) shows some technical terms used in Egyptian Supreme legal texts. 
In fact, it is crucial to consider these terms when attempting to understand any particular legal text.

3- Legal languages are ancient, a legacy, a renewable, and vital at the same time, but they continually evolve. Legislators introduce new terms, adopt new terms, and renew existing ones through this process (p.23). According to Tiersma (1999), "legal language gravitates towards great formality; it naturally gravitates toward archaic language" (p.95-96). This means that legal language vocabulary is infused with some archaic legal expressions to give it a distinctive character. For example, the

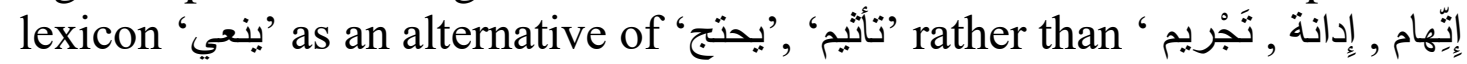

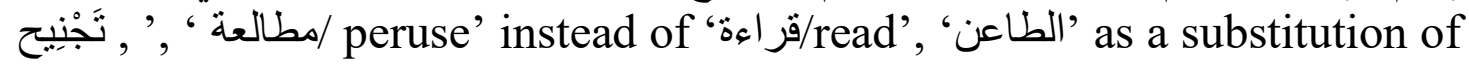
'اعترض' 'الثاكي' or and so on. In addition, Crystal and Davy (19人7) argue that "there are specific archaic adverbs which are a combination of referential elements to avoid challengeable changes of meanings such as: 'here' 'there' and 'where' with certain prepositions: of, after, by, under... etc. (p. 213). Table (2) below, illustrate some adverbs which are a combination of referential elements:

\begin{tabular}{|c|c|c|c|}
\hline $\begin{array}{l}\text { English } \\
\text { Language }\end{array}$ & Arabic language & English Language & $\begin{array}{l}\text { Arabic } \\
\text { language }\end{array}$ \\
\hline $\begin{array}{l}\text { hereto / } \\
\text { thereunder }\end{array}$ & بمقتضِي / بِمُوجِبٍ & hereinafter referred & الْلَشُشَارُ الِيُّهُهُ فِيمَا بَعْدَ \\
\hline hereunder & ادناه & hereinbefore & مَا وَرْدِ أَعْلَِِِ \\
\hline hereof & حَنَّى الآلانِ & thereof & باللَِّنْبَةِ لـ \\
\hline thereon & إنْطِلَاَفًا مِنْ / تَعَوْ يِلَا عَلِْي & herein & فِي هَذَا \\
\hline
\end{tabular}

Table 2. Adverbs which are a combination of referential elements.

4 - Legal language is scientific and practical: legal language expresses legal facts, legal systems, and legal processes, such as contracts and agreements, as well as its technical nature. The use of this language is practical in service of the law since it forms the basis of the law and applies it in an accurate manner (p.26). 
5- Legal language is a straightforward language, which means each word has its own meaning and each term in a legal phrase is chosen based on a specific arrangement to achieve accuracy and clarity. Furthermore, the absence of rhetorical devices such as metaphor, simile, metonymy, and pun can enhance accuracy and clarity (p. 28). In this context, Sabra (1995) states, "legal texts are highly concerned with the exactness of reference, so they tend toward lexical repetition, and therefore functional redundancy". For instance, the following sentence is an example of lexical repetition of reference:

\begin{tabular}{|c|c|}
\hline $\begin{array}{l}\text { Due to the financial differences } \\
\text { between the appellant and his uncle, } \\
\text { "the victim's father," the latter has } \\
\text { gotten trust receipts from the } \\
\text { appellant. }\end{array}$ & 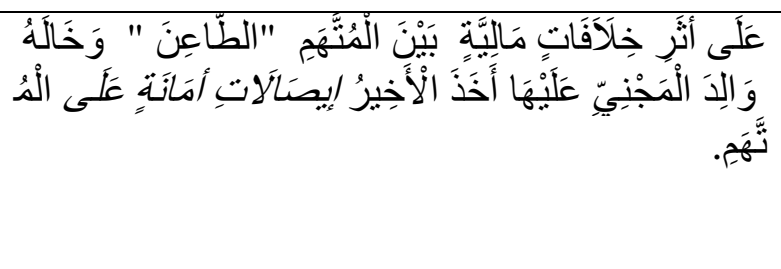 \\
\hline
\end{tabular}

Here, if we opt for the objective pronoun 'him/ه' instead of the word 'the accused' in the phrase 'إيصَالَاتِ أمَانَةٍ عَلَى 's the latter has got trust receipts on him ', this certainly creates misunderstanding and opacity. This repetition is functional in order to disambiguate the intended meaning. In addition, Tiersma (1995, p. 88) points out some special uses of some legal lexicon. These special uses can be applied upon the legal texts of Egyptian Supreme as follows: (هًَا /

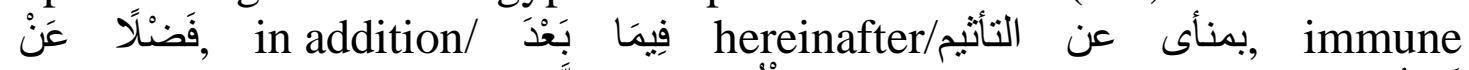

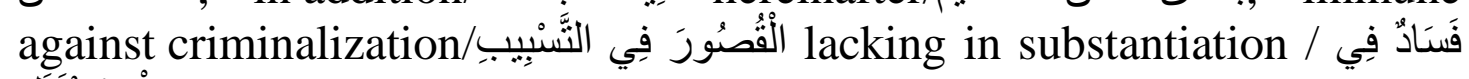

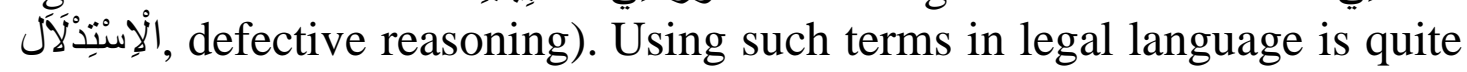
different from using them in ordinary one. The word 'the same' usually implies comparison to a similar object or person, but in legal use it refers to sameness of reference. For example:

the same evidence were not satisfactory for another accused.

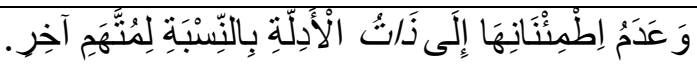

In this sentence above, the phrase 'the same-ذَّا ' refers to the word

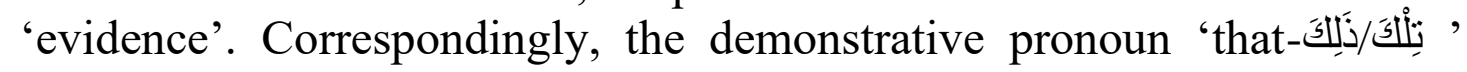
can conveniently substitute the phrase 'the same.' Also, the determiner

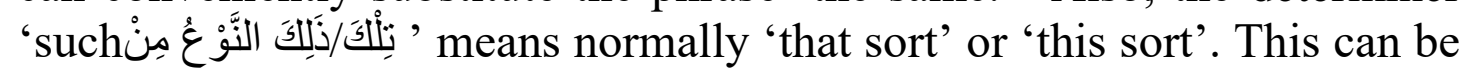
observed in a legal context as follows: 
and then the ruling concluded that the

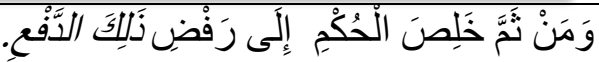
appeal was denied.

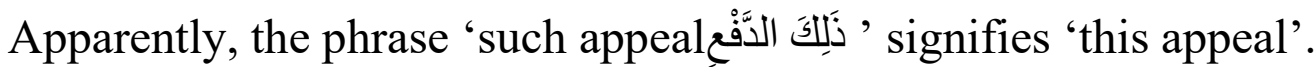
So, such determiners act in the same way as the demonstrative pronoun 'this.' In a similar vein, Alcaraz and Brian (2002) point out that there is a common use of doublets combined in pair (p. 9). Nouns, verbs, adjectives, and even prepositions can be included in such words. For example:

\begin{tabular}{|c|c|}
\hline null and void & لَا غَغِيَا وَبَاطِكَا \\
\hline with malice aforementioned and Premeditation & سَبْقَ الْإِصنْرَارِ وَالتنَّرَصُّدِ \\
\hline possessed and acquired & حَازَ وَأُحْرُزْ \\
\hline $\begin{array}{l}\text { lacking in substantiation, and defective } \\
\text { reasoning }\end{array}$ & 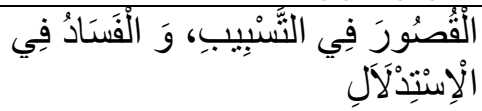 \\
\hline accord and satisfaction & 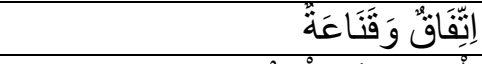 \\
\hline aid and abet & 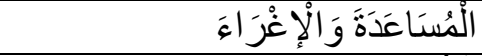 \\
\hline each and every & كُلُْ \\
\hline
\end{tabular}

\subsection{Textuality features of the Egyptian Forensic Texts}

A text's textuality is defined as the use of language characteristics to identify a text's quality for the addressee. (De Beaugrande \& Dressler, 1981/2002) define textuality as a combination of seven standards: Cohesion, Coherence, Intentionality, Acceptability, Informativity, Situationality, Intertextuality. Textuality encompasses all aspects of the construction and interpretation of legal texts, including their emergence and ambiguity. Therefore, the words of the legal texts provide an appropriate intertextual context for any analysis. 'Cohesion' and 'Coherence' refer to the harmony of a text's structure as a whole unit of components such as recurrence, parallelism, paraphrase, pro-forms, anaphora, use of tense and junction to represent and convey knowledge. For example, the parallel structure below: 


\begin{tabular}{|c|c|c|}
\hline C:10 & $\begin{array}{l}\text { Rather, the contradiction between the } \\
\text { legal evidence provided by the } \\
\text { confession issued by the appellant, and } \\
\text { the technical evidence provided by the } \\
\text { autopsy report. }\end{array}$ & 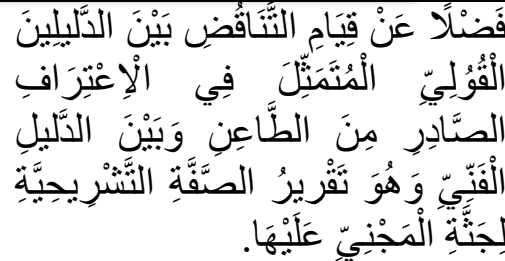 \\
\hline C:17730 & $\begin{array}{l}\text { Judgment condemned the murder, } \\
\text { attempted murder, participation in and } \\
\text { agreement with premeditation and } \\
\text { monitoring... setting up, managing and } \\
\text { joining a group established in violation } \\
\text { of the provisions of the law. }\end{array}$ & 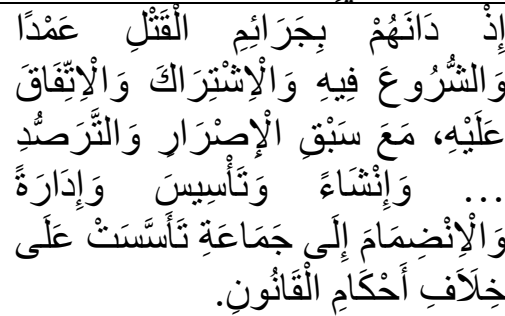 \\
\hline
\end{tabular}

Parallelism in the example above represents an identical balance within the sentence of similar words, phrases, or clauses that have the same grammatical structure. By using this technique, legal language becomes more interesting, forceful, and clear. Similarly, there are similar clauses in both (the two legal evidences represented in the confession issued by the appellant and in the technical evidence, which is the autopsy report of the victim's body), in the structure of the past verbs (condemned, attempted, participated-agreed upon, premeditated and monitored), and in the nominalization (establishing, managing and joining) which is consistent in expression and function. Parallelism is observed in Supreme legal texts in which the same verb, noun, adverb, and adjective forms appear consistently. Coherence is the continuity of senses in a text by the use of related meanings when there is causality, reason, purpose, time in the text. Coherence concerns the ways in which the components of the textual world are related and unified together. For example, if the text is reflected as "Supreme Appeal of Criminal Chambers" this legal text may be exemplified in mechanical terms as follows:

\begin{tabular}{|c|c|c|}
\hline C:10017 & $\begin{array}{l}\text { Intent killing. Criminal intent, Crime } \\
\text { Constituent Essentials, the trial court } \\
\text { Its authority to value the evidence. }\end{array}$ & 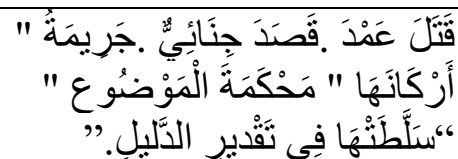 \\
\hline
\end{tabular}

In terms of 'Intentionality', the author of legal text intends to achieve a specific goal in a cohesive and coherent way together via the legal words. For example:

$$
\begin{array}{l|l}
\mathrm{C}: 10017 & \begin{array}{l}
\text { In regard to the appeal submitted by } \\
\text { the accused person sentenced to }
\end{array}
\end{array}
$$

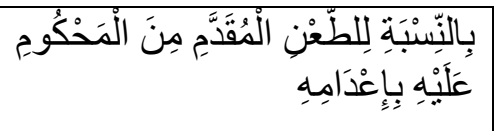


death.

The text addresses (a criminal person), and (the death penalty), and is intended to convey the belief that (the criminal person sentenced to death). In terms of 'acceptability,' it means that the recipients of a text uses it for functional purposes in expectation of receiving something specific from that criterion. Consequently, a coherent set of components is required to ensure that expectations correspond with what is meant in the legal text. For example:

\begin{tabular}{|c|c|c|}
\hline C:11229 & $\begin{array}{l}\text { Upon the court's ruling the } \\
\text { convicted person's appeal was } \\
\text { accepted, and the Public } \\
\text { Prosecution presented the case, as } \\
\text { presented, and rejected the appeal } \\
\text { and approved the death sentence. }\end{array}$ & 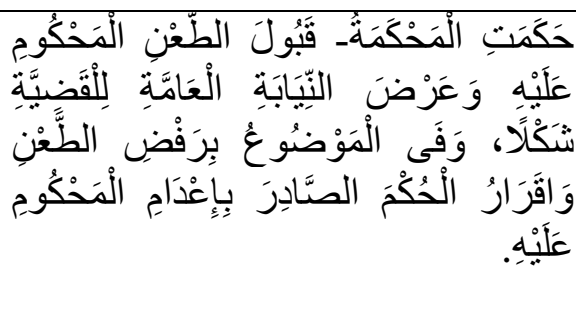 \\
\hline
\end{tabular}

In the forensic language, judge-criminal accepts a ruling as a sentence of his language. Informativity standard concerns with how unexpected, expected or known, unknown are the occurrences in the text.For example,

\begin{tabular}{|c|c|c|}
\hline C:11229 & $\begin{array}{l}\text { Thereinafter, the ruling dealt with the } \\
\text { defendant objection's defense, raised and } \\
\text { responded to with what disputed, and the } \\
\text { ruling was issued unanimously by the } \\
\text { members of the court... then the death } \\
\text { sentence for the convict should be } \\
\text { approved. }\end{array}$ & 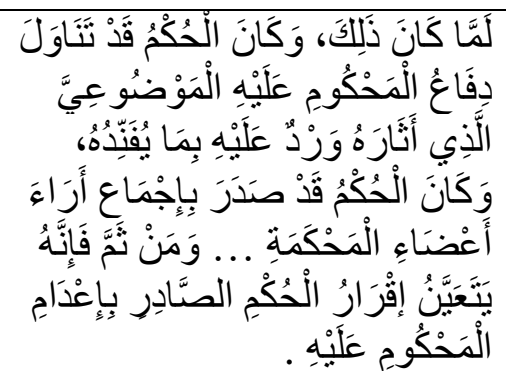 \\
\hline
\end{tabular}

In this context, judgment articles, propositions, the content of the ruling, and be attentive to the legal text should be known. Situationality dictates that a forensic text is relevant to a particular context of occurrence. This is related to the context and the situation in which the addressee is in. In some cases, a "Court of Supreme" should confirm the ruling or judgement during the execution of the convict. Lastly, intertextuality, i.e., the rule-making process draws upon an extensive repertoire of written texts. Knowledge, experience, and previous 
decisions significantly impact the present ruling. That is why the construction and the response of a given forensic text depend on the participants' knowledge of other forensic texts.

\section{Forensic Discourse Analysis}

Coulthard and Johnson (2007) propose that "This discourse can be identified by a particular selection and use of grammar, vocabulary and structure (p.8)". Therefore, approaching a forensic text in a forensic context requires some significant considerations to distinguish it from other texts in other contexts. This text includes particular choices of lexical and grammatical terms to simplify the understanding of obligations and responsibilities for action.

\subsection{Grammatical Words in the Three Forensic Cases}

In forensic cases the choice and frequency of particular grammatical and lexical items are distinctive. One of the ways to answer the question of which lexicons are used differently in legal texts, is to look at frequency lists across collections or corpora of texts selected from the Egyptian Supreme court which reveal an extensive array of text types indicating particular legal language different from language in general. First, the most frequent words in the three cases are compared and illustrated in table (3) as follows:

\begin{tabular}{|c|c|c|}
\hline $\begin{array}{l}\text { Supreme Appeal No. } \\
\text { of } 88 \text { Judicial year. }\end{array}$ & English language & Arabic language \\
\hline C.10017 & $\begin{array}{l}\text { (the, from/of, and, or, in, } \\
\text { to(infinitive),hereafter.)(conjunction } \\
\text { /discourse marker) any, appeal (noun) } \\
\text { verb (to be) is). }\end{array}$ & 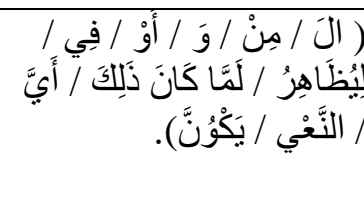 \\
\hline C.IVVT. & $\begin{array}{l}\text { (the, from/of, and, or, in, to (infinitive), } \\
\text { hereafter (conjunction/discourse } \\
\text { marker) any, terrorism (noun) is). }\end{array}$ & 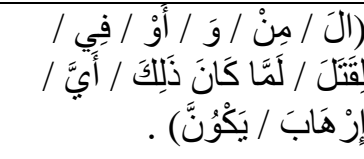 \\
\hline C.11229 & $\begin{array}{l}\text { (From, the, and, to(preposition), verb } \\
\text { (to be). }\end{array}$ & (مِنْ / الَ / وَ / إِلَى / كَانَ). \\
\hline
\end{tabular}

Table 3 The most frequent words in the three cases. 
One of the interesting things about the frequency lists above is the differences between grammatical words since they are the most prevalent items in all texts. A grammatical analysis indicates that the most frequent words in these legal texts are: 'or', 'and' 'any', and 'to (infinitive)'. Also, the preposition 'to' is more frequent than the infinitive 'to' and the noun 'appeal.' By comparison, these words occur in the following frequency places as figure (1) illustrates: $($ or $=150 ;$ any $=29$; to (preposition $=313$; to $($ inf. $)=375$; and $=1166)$.

\section{The Differences between Grammatical Words \\ or}

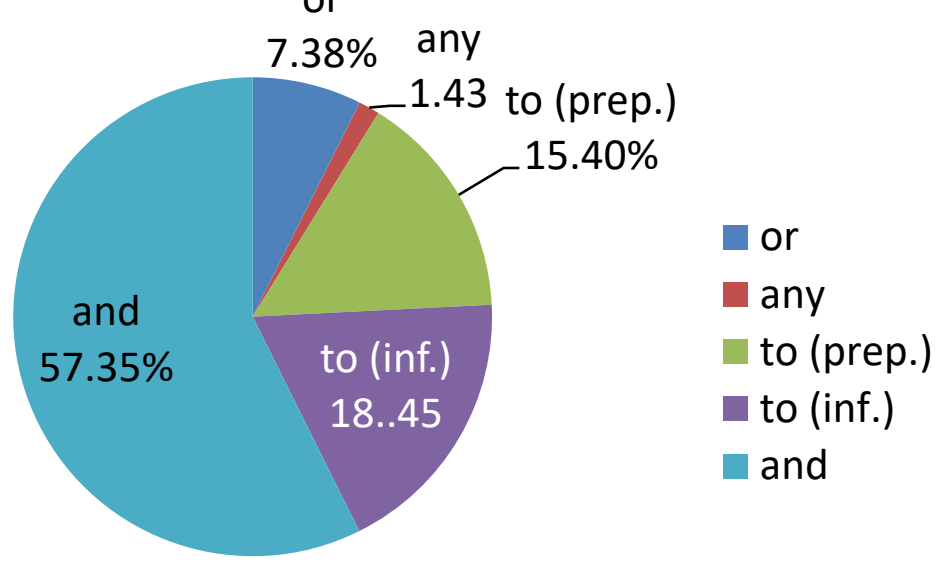

Figure 1 illustrates the differences between grammatical words classifications in the three cases.

The pie chart above shows the proportions of differences between grammatical word classifications in the three cases. The conjunction (and) has the largest proportion (57.35\%). Comparing (to+ inf.) and (to+ prep) consecutively, the ratios are about the same $(18.45 \%$ and $15.40 \%)$. Coordinating conjunction (or) comes next by $38 \%$. Quantity (any) has the lowest proportion of 1.43 $\% \%$. All five words appear in the three legal texts in combination with other characteristic syntactic and lexical distinctive features. The higher frequency of and, for example, is a consequence of the much more frequent incidents occurring by the accused people, linking between the nouns or verbs and passive constructions. The frequency of the word 'or' in legal texts results from the 
communication task of ensuring inclusivity. This is essential to cover all consequences in relation to the appellants either the incidents conveyed by a verb or expressed by nominalizations to indicate completion of a direct impact on word choice. In most cases, 'and' and 'or' refer to additive and disjunctive meanings in ordinary language.

\section{2 Lexical Items Most Used in the Three Forensic Cases}

Specifically, lexical items of the Supreme court reveal different frequencies by comparison with an ordinary language. In the three cases, the most frequent lexical items that appeared are as follows:

defendant/ appeal/ homicide/crimes/ evidence, terrorist, appeal/murder/ objection/execution/ judgment/ law/commit

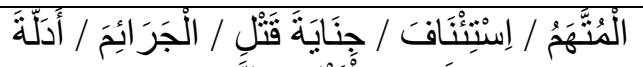

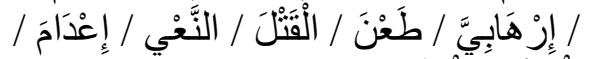

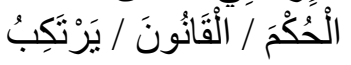

The following chart illustrates the proportions of these lexical items classifications in the three cases. 'Judgment' is the largest proportion by $42.13 \%$. Next, the proportion of 'evidence' by $23.73 \%$, then comes the word 'Homicide' by $18.40 \%$, whereas 'appeal' is $12.53 \%$. finally, the word 'objection' is the least proportion by $3.20 \%$.

\section{Most Frequent Lexical Items}

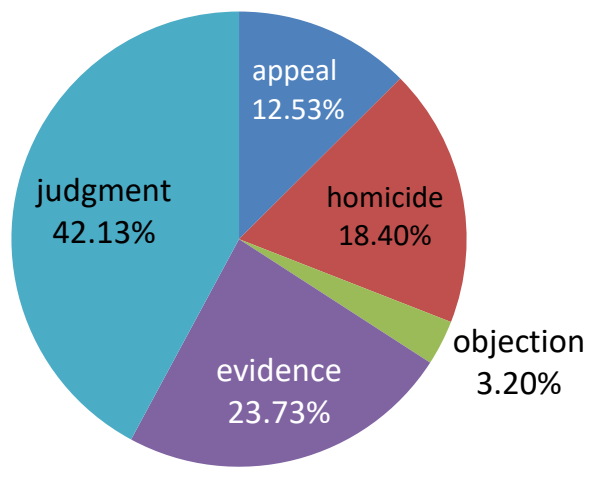

$$
\begin{aligned}
& \text { appeal } \\
& \text { homicide } \\
& \text { objection } \\
& \text { evidence } \\
& \text { judgment }
\end{aligned}
$$

Figure 2 Most Lexical Items Used in the three cases.

There is one word, though, that requires to be discounted from this list, this word is (appeal) because each of its (47) occurrences in the three 
texts occur as a lexical noun or verb, but their presence as a high frequency item nevertheless points to its distinctiveness as part of the different grammatical

set in the forensic texts, and in legal language as a whole. The major number of frequent lexical words implies that forensic or legal texts are unusually grammatically complex and over-lexicalized written texts. The majority of the words list above are nouns and refer to the individuals involved in the court judgment and to the cause itself as a request by the defendants. The two lexical verbs that are present in the list appeal and commit are important in relation to the function of the ruling and the notion of selectivity and inclusiveness already in the use of the conjunction and. The verb commit is generally used to introduce the noun crime that give provisions and inclusions that hold important interpretative details. Some examples of the distinctive patterns among the occurrences of commit in the three cases are:

a. the verb commit occurs (14) times accompanied by crimes in passive constructions for example:

\begin{tabular}{|c|c|}
\hline $\begin{array}{l}\text { The three crimes were committed in a } \\
\text { short period of time }\end{array}$ & وقلد رلُُكبت الجنايات الثلاثة في فترة قصبرة من \\
\hline $\begin{array}{l}\text { The two crimes were committed at the } \\
\text { same time }\end{array}$ & الجنايتان قد ررتُكبتا في وقت و احد \\
\hline
\end{tabular}

b. commit [object] active voice as follows.

\begin{tabular}{|c|c|}
\hline $\begin{array}{l}\text { The convicted accused have all } \\
\text { committed the facts attributed to them }\end{array}$ & 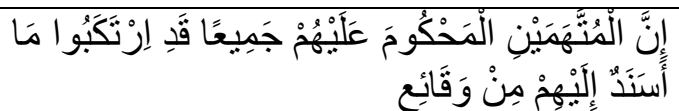 \\
\hline They all committed crimes & لَنَكَبُو ا الْجَرَ ائِحَ \\
\hline
\end{tabular}

The verb appeal occurs (47) times in the three cases. It is used six times as a verb in constructions like: appeal plus prepositional phrase, a transitive verb that can take a direct object. In other words, the actions of the transitive verb appeal are done to someone or something, or nonfinite (Gerund).

The table (4) below displays the occurrence of the verb appeal: 
To appeal against its inaction to conduct an investigation.

As attested in the minutes of the session or ruling except by appealing against forgery.

A final distinguishing feature in the use of appeal in the Supreme court can be detected when its frequency is compared by the three cases. The verbal use of appeal introduces provisions of the Supreme court, whereas the verbal use of commit introduces various crimes (in most sentences). This use underlines the dominance of these functions in forensic linguistics and show clearly what cases are about. In addition, the repetition of lexical noun items such as (defendant/murder/ judgment /homicide /criminal/ terrorist) ... etc., rather than the use of pronoun substitutes, produces frequency information that underlines the key semantic fields present in legal written texts.

Other marked lexical features of written legal texts are specific prepositional phrases (pursuant to عملًً بـ , على , at the instance of , in addition to an intensive use of performative constructions that perform certain actions, or express the action of doing, (the agent) to declare /to admit / to sentence, to object ...etc., Moreover, a more frequent use of passives, and unusually long sentences. For example, in the case number (11229), the preamble of the sentence includes average length of (85) words long. Finally, there are sometimes punctuation marks and sometimes not which can create ambiguity in understanding.

\subsection{Thematic structure of Forensic Texts}

The thematic structure of the three criminal cases examined is relatively helpful to the identification of topic area 'Forensic texts' and the natural progression of organization of structure. The 'internal organization' of the information unit, relates to the way in which 'Given and New' information is distributed within the forensic text. Characteristically, the legal legislators thematize given information before new information. The 'unmarked' sequencing of information structure is taken to be Given-New. Naturally, information units which are initial in a discourse contain only new information. Brown and Yule (1983) point out five syntactic forms which are regularly discussed in association with 'Given' information 
(p.171). These syntactic forms include:

1. Lexical units which are mentioned for the second time as follows, particularly those in definite expressions.

\begin{tabular}{|l|c|}
\hline \multicolumn{1}{|c|}{ English language } & Arabic language \\
\hline 1. Under the weight and threat of the \\
authority of the case officer ... with the \\
indication of the officer being alone \\
testifying about the occurrence of the \\
arrest (Case: 10017).
\end{tabular}

2. Lexical units which are presented as being within the semantic field of a previously mentioned lexical unit as follows, again particularly those in definite expressions.

\begin{tabular}{|c|c|}
\hline English language & Arabic language \\
\hline $\begin{array}{l}\text { 2. A cult founded in violation of the } \\
\text { provisions of the law ... and assaulting } \\
\text { others. Terrorism was the instruments to } \\
\text { implement these purposes (Case: } 11229 \text { ). }\end{array}$ & 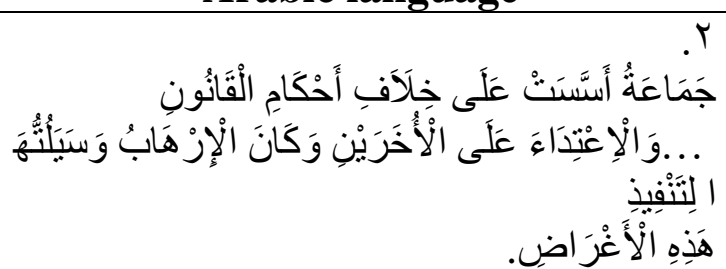 \\
\hline
\end{tabular}

3. Pronominals used anaphorically following a full lexical form in the preceding sentence as follows:

\begin{tabular}{|c|c|}
\hline English language & Arabic language \\
\hline $\begin{array}{l}\text { 3. People claimed they are Egypt's } \\
\text { Ajnad (Case: } 17730) \text {. }\end{array}$ & 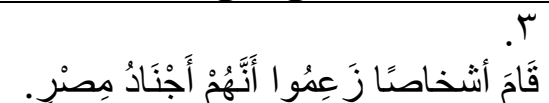 \\
\hline
\end{tabular}

4. Pronominals used exophorically (to refer to the physical context of situation) where the referent is present, as follows:

\begin{tabular}{|c|c|}
\hline English language & Arabic language \\
\hline $\begin{array}{l}\text { 4. Whereas the appellants... having } \\
\text { convicted them of intentional murders, } \\
\text { attempted them, participated in and } \\
\text { agreed upon ( } \mathrm{C}: 17730) \text {. }\end{array}$ & 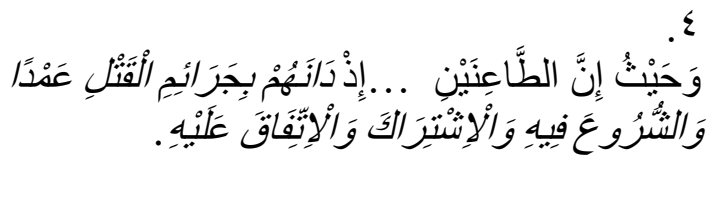 \\
\hline
\end{tabular}

The interpretation runs as the crimes of intentional murders, 
attempted them, participated in and agreed upon. This kind of reference is called exophora, since it refers to a crime outside the text altogether.

5. Pro-forms as in follows:

\begin{tabular}{|c|c|}
\hline & \\
\hline $\begin{array}{l}\text { 5. a. For the validity of the force of a } \\
\text { judgment in criminal matters, there is a } \\
\text { requirement that a provision has already } \\
\text { been pronounced in the criminal trial } \\
\text { (C: } 17730) \text {. }\end{array}$ & 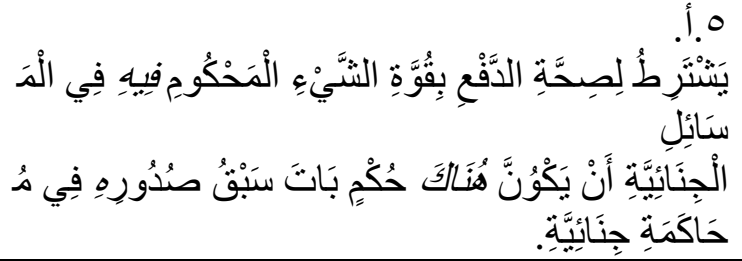 \\
\hline $\begin{array}{l}\mathrm{d} \text { seized his } \\
\text { rcibly, and } s\end{array}$ & 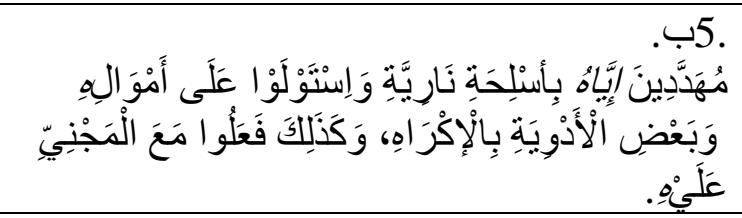 \\
\hline
\end{tabular}

The pro-forms 'there/هناك' and 'so they did//كذلك فعلوا' are concerned with particular syntactic realizations, where the main elements in the second sentence is held to be in some sense 'given'.

a. judgment in criminal matters, b. the defendants. Pro-form is a word or phrase that replace the place of another word (or word group) in a sentence. Crystal (2008) defines pro-form as "a term used in some models of grammatical description to refer collectively to the items in a sentence which substitute for other items or constructions (p.390). These pro-forms are pronouns, but other words such as (here, there, so, and do) can also function as proforms ${ }^{(5)}$.

\section{Ambiguity of Legal Language of the Egyptian Supreme Court}

Language cannot exist without ambiguity since it is a phenomenon that usually occurs in human communication on a daily basis. Due to their technical nature, legal texts are viewed as a source for ambiguity analysis. Rodman (1983) explains "A word or a sentence is ambiguous if it can be understood or interpreted in more than one way (p.169)". The meaning properties of some legal terms are contrary to the meaning properties of this language because they refer to (a word, phrase, or sentence) that has more than one meaning. As Leech (1981) points out, an 
expression is considered ambiguous when it is capable of more than one interpretation (p.30).

This ambiguous expression can occur in one word or one sentence/phrase, whether it is because of lexical or structural ambiguities. Therefore, ambiguity is a linguistic feature that can occur in spoken and written language, resulting in difficulty understanding what the speaker or the writer intended (Ullmann, 1977, p. 156). Ambiguity, according to Crystal (1988, p.15) and Hartmann and Stork (1976, p. 11), is the reference to a word, sentence or a construction which admits more than one interpretation.

Ambiguity occurs as a result of either a lack of understanding of the language or the limited linguistic capabilities of those who are charged with preparing the written legal texts. Legal text that follows either a complex drafting style or is unclear and difficult to understand. This can also occur in formulations when a term or meaning is used to refer to something, then used to refer to something else. So, when drafting the legal text, it is taken into account the exercise of prudence with regard to drafting the legal text and considering the terms used in drafting the legal text ${ }^{(4)}$. There is a distinction between ambiguity and vagueness. An ambiguous word has various different meanings in different contexts and is restricted to one meaning. However, the meanings of a vague term in different contexts have something in common and the context can add information outside its meaning. Tuggy (1993) defines vagueness as "a lexeme with a single but nonspecific meaning (p. 168)."

\subsection{Types of Ambiguity}

There are two types of legal ambiguity that appear in written legal texts as follows:

1. Lexical or semantic ambiguity: this category arises when a word has more than one meaning.

2. Structural or syntactic ambiguity: this category arises when the role of a word in a sentence is unclear. 
-If the authority is to discharge its legal duty, it needs government support.

4) to allow someone officially to leave somewhere, especially a hospital or a court of law

-More than half of all prisoners discharged (= allowed to leave prison) are convicted within two years.

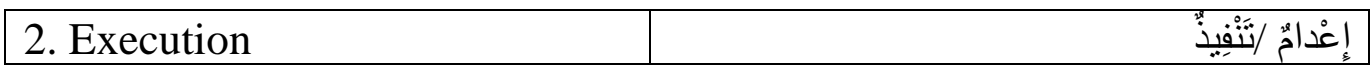

1) when someone is killed as a legal punishment

-The executions will be carried out.

2) to complete or perform as required as in fulfilling one's obligations under a court order.

-Sometimes in the execution of their duty the police have to use firearms.

-The judgment shall take effect upon its execution.

\begin{tabular}{|c|c|}
\hline 3. Good & 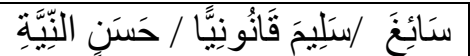 \\
\hline
\end{tabular}

\section{1) Effective}

-For other good and valuable consideration, the defendants agree among themselve as follows.

2) Legally sufficient

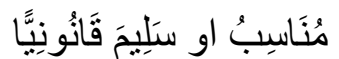

The stigmatization contained in Article ( 86 bis of the Penal Code is "a good cause".

3) to be qualified under relevant laws and regulation. مُوَ هَّلْ لـ لــ

-The Brotherhood is a cult duly organized, invalidly existing and they are not in

good standing as a legal cult under the laws of the Constitution.

4) to be honest, fair

حَسَنْ النِيَّةِة

-The defendants shall be interrogated in good faith.

\subsection{Structural Ambiguity of Legal Texts of the Egyptian Supreme Court}

Structural ambiguity occurs at the sentence level when there is more than one complete structural meaning that may be assigned to a construction. This occurs if there is a sentence in which the words relate 
to each other in various ways, without any words being ambiguous (Hurford \& Heasley, 2007, pp.129-130). Therefore, structural ambiguity of legal texts can lead to different interpretations. According to the methods used in presenting the data, lexical ambiguity includes different parts of speech, namely nouns, verbs, and adjectives. Each of the three subcategories is discussed below.

1. Nouns: Lexical ambiguity relying on nouns can be created by homonymy and polysemy as follows:

\begin{tabular}{|c|c|c|}
\hline C: 17730 & $\begin{array}{l}\text { The appeal had } \\
\text { been fulfilled its form } \\
\text { prescribed by law. }\end{array}$ & 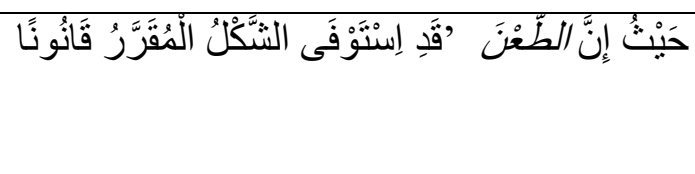 \\
\hline
\end{tabular}

The noun الطَّعنَ can be interpreted in more than one way. The polysemy homonymy of the noun الطَّعْنَ meaning both: a. the act of pushing a knife into someone, b. a wound caused by stabbing, and c. a request made specifically to a court of law to change a previous ruling. Only context disambiguates the intended meaning, whether linguistic or situational.

\begin{tabular}{|c|c|c|}
\hline$C: 1 \cdots 1 V$ & $\begin{array}{l}\text { and the sentence embraced a } \\
\text { film of the incident } \\
\text { contradicting their fixed } \\
\text { actualities. }\end{array}$ & 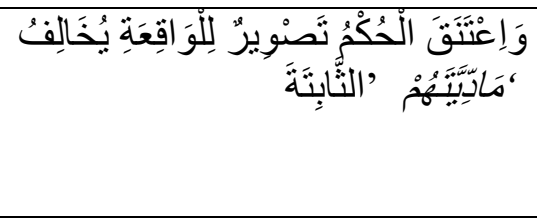 \\
\hline
\end{tabular}

The noun 'مَادِيَّتَهُعْ can be interpreted in more than one way. The

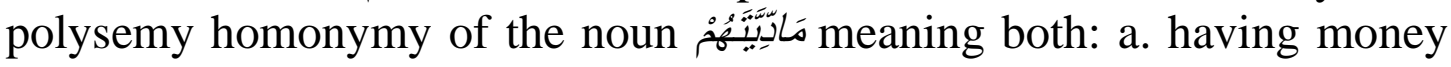
and possessions, b. something which is known to have happened or to exist, especially facts for which proof exists, or about which there is information.

\begin{tabular}{|l|l|r|}
\hline $\begin{array}{l}\text { C: } \\
\text { IVVr. }\end{array}$ & $\begin{array}{l}\text { Hence, erroneous } \\
\text { statement is declined in } \\
\text { allegations of data } \\
\text { collection or defective } \\
\text { inferred in reasoning. }\end{array}$ & \\
\hline
\end{tabular}

The noun can be interpreted in more than one way. The 
polysemy and homonymy of the noun قَّلَّing meaning both: a. a short sleep 'a nap', especially during the day or b. a statement that something is true or is a fact, although other people might not believe it.

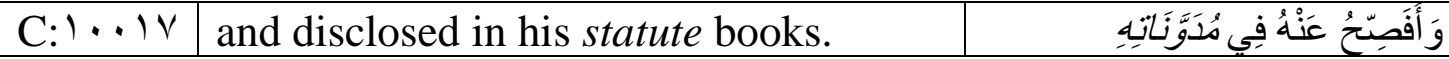

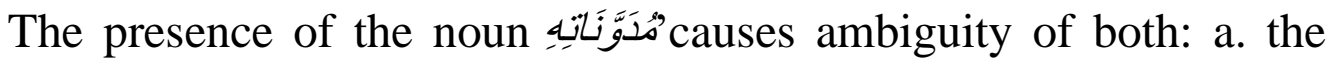
collection of a single writer's work or of writing about a particular subject, or b. a large amount of written and sometimes spoken material collected to show the state of a language or a diary (regular record of your thoughts, opinions and experiences 'blogs') that you put on the Internet for other people to read, c. the statute book formally approved and written down in a law court.

\begin{tabular}{|l|l|l|}
\hline C: IVVr. & $\begin{array}{l}\text { by a report in the } \\
\text { Clerk's Office or to the } \\
\text { Prison Commissioner. }\end{array}$ & \\
\hline
\end{tabular}

The noun phrase قَلَّمْ كُنَّاب can be interpreted as a. a long thin object used for writing or drawing with ink or $b$. a person who works in a courtroom or an office, dealing with records or performing general office duties.

\begin{tabular}{|c|c|c|}
\hline$C: 1 \ldots 1 V$ & $\begin{array}{l}\text { refer to the trial court, } \\
\text { which are reported, } \\
\text { considered, and } \\
\text { appreciated. }\end{array}$ & 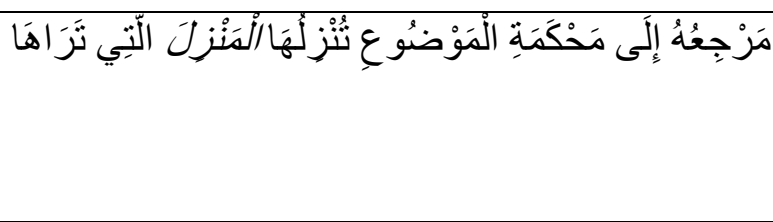 \\
\hline
\end{tabular}

On the other hand, what is intended as the noun 1 i lis the common meaning noun indicating a building which people live in, or b. to have a position higher or lower than others. Courtroom context and rulings can be used to disambiguate this structural ambiguity. All these nouns change meaning depending on the context in which they are used.

2. Verbs: among the written legal texts in which the ambiguous element is the verb resulting from having a meaning that conflicts with expectations and knowledge of the world. This can be observed using legal terms as follows: 


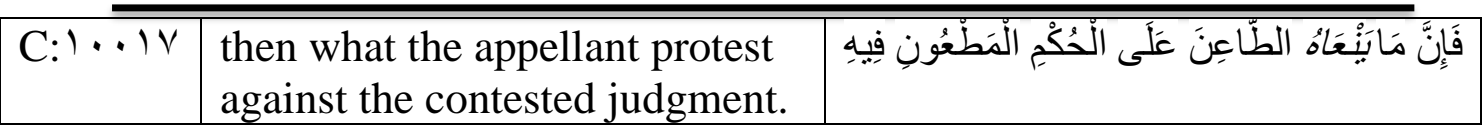

The verb بَنَعَيْي is made ambiguous by the two opposite meanings of it. It may mean both a. بَ بَعََيْي to mourn, i.e., to feel or express profound sadness, especially because of someone's death, or b. 'to criticize or protest by expressing disapproval of someone or something. If the first meaning is applied, the meaning is interpreted as profound sadness at someone's death. However, if the second meaning is introduced, the text sounds coherent with the legal context.

\begin{tabular}{|c|c|c|}
\hline $\mathrm{C}: 1 \cdots \mathrm{IV}$ & $\begin{array}{l}\text { - and it was stamped by the } \\
\text { invalidity of the procedures } \\
\text { affected it }\end{array}$ & 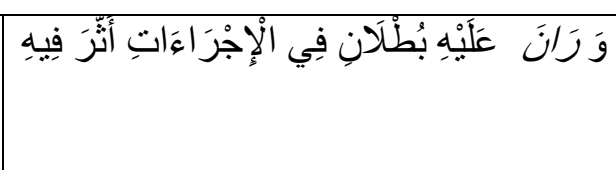 \\
\hline
\end{tabular}

The verb رَانَ has two different meanings: a. rusted upon, and b. to leave a mark on something which is difficult to remove and blemish it or stigmatize. However, if the second meaning is introduced, the text sounds coherent with the legal context.

\begin{tabular}{|c|c|c|}
\hline C:IVVT. & $\begin{array}{l}\text { The judgment was dismissed owing to } \\
\text { the inadequate response. }\end{array}$ & 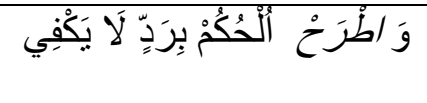 \\
\hline
\end{tabular}

The verb اطُرَْْ is made ambiguous by the many opposite meanings of it. It means a) to subtract, b) to remove a number from another number, c) to offer or state a possible plan or action for other people to consider, d) to dismiss e) to decide that something or someone is not relevant and not worth considering. However, if (d) or (e) meaning is introduced, the text sounds coherent with the legal context.

\begin{tabular}{|l|l|l|}
\hline C:1.. IV & $\begin{array}{l}\text { and the sentence has } \\
\text { embraced a film of the } \\
\text { incident contradicting } \\
\text { their fixed actualities }\end{array}$ \\
\hline
\end{tabular}

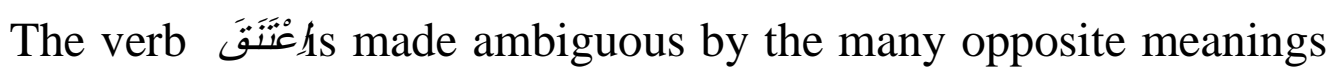
as follows: a. to accept something enthusiastically, b. to hold someone tightly with both arms to express love, liking or sympathy, or when greeting or leaving someone, c) to offer or state a possible plan or action for other people to consider, d. to include something, often as one of a 


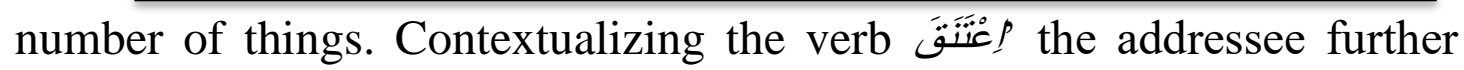
realizes that $(\mathrm{d})$ is intended to convey the core meaning via the linguistic and situational context i.e., embrace.

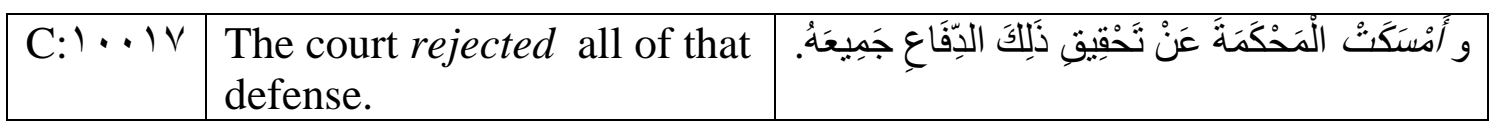

The verb أَمْنَكَكْْْ is made ambiguous by the many different meanings such as: a. to hold, catch or restrain, b. to take and keep something in your hand or arms, c. to control the actions or behaviour of someone by force, d. to dismiss or to refuse to accept, use or believe. However,

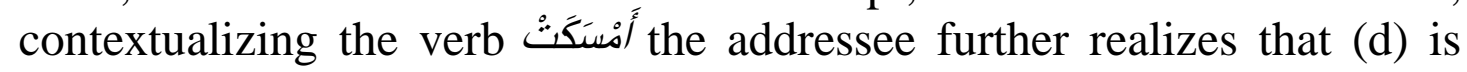
intended to perform the core meaning via the linguistic and situation context, i.e. the court rejected all of that defense investigations behind it.

\begin{tabular}{|c|c|c|}
\hline $\begin{array}{l}\text { C: } \\
\text { lirq }\end{array}$ & $\begin{array}{l}\text { Whereas what the appellants raised that the } \\
\text { Muslim Brotherhood was announced as a } \\
\text { charitable society. }\end{array}$ & 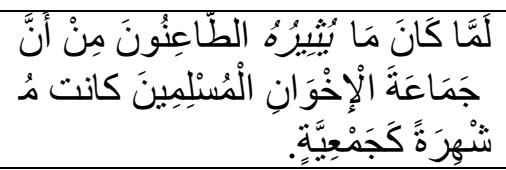 \\
\hline
\end{tabular}

The verb يُشيُير has two different meanings a. to increase, i.e., to cause something to increase or become bigger, better, higher, etc., and b) to cause to exist. However, if the second meaning is intended, the text sounds coherent with the legal context.

\begin{tabular}{|c|c|c|}
\hline$C: 1 \cdots 1 V$ & $\begin{array}{l}\text { The judgment has ascribed the } \\
\text { description of the confession }\end{array}$ & 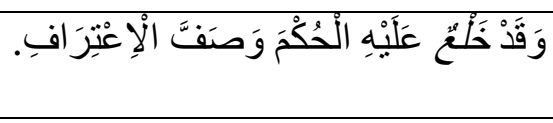 \\
\hline
\end{tabular}

The verb follows: a) to extract, take off or uproot, b. to ascribe or label, i.e. a word or a phrase which is used to describe the characteristics or qualities of people, activities or things, often in a way that is unfair to stigmatize them. If the first meaning is applied, the meaning is interpreted as to extract or take off something. However, if the second meaning is introduced, the meaning sounds coherent with the legal context, i.e. the court rejected all of the defense investigations. On the other hand, if the second meaning is introduced, then the text sounds coherent with the context, i.e., the confession is being described. 
3. Adjectives: word (s) used to identify or quantify individual people and unique things. They are usually positioned after the noun(s) or pronoun in Arabic that they modify, or before the noun (s) or pronoun in English.

\begin{tabular}{|c|c|c|}
\hline $\mathrm{C}: 1 \cdots 1 \mathrm{~V}$ & $\begin{array}{l}\text { This act is imprudent and } \\
\text { deficit. }\end{array}$ & 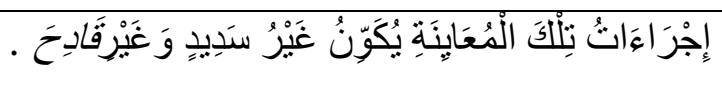 \\
\hline
\end{tabular}

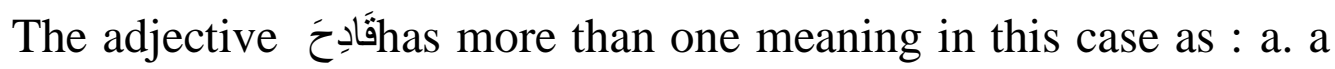
part of a gun which causes the gun to fire when pressed, or b. an event or situation, etc. that causes something bad to start. by the linguistic context of the word, the meaning (b) becomes coherent with the legal context.

\begin{tabular}{|c|c|c|}
\hline$C: 11$ rYq & $\begin{array}{l}\text { The judgment was dismissed owing to the } \\
\text { inadequate response. }\end{array}$ & رَدِّفَّاصِر. \\
\hline
\end{tabular}

It can be observed from the contextual ambiguity of the adjective 'قَاصِرِ where the unit of information reporting a trial can be interpreted as: a. younger than the lowest age at which a particular activity is legally or usually allowed, b. someone who is too young to have the legal responsibilities of an adult. However, this adjective in this context means 'having little importance, influence or effect, defective, especially when compared with other things of the same type '. The context, either linguistic or situational, determines the intended meaning of written legal texts when there are lexical and structural ambiguities.

\subsection{Factors Generating Structural Ambiguity in the Egyptian written legal texts}

Legal language has different factors that cause structural ambiguity. This study lists seven factors generating this type of ambiguity as follows:

\subsubsection{Ellipsis}

In legal language, an ellipsis is a linguistically appropriate omission of words that can be understood or inferred to avoid redundancy. Ellipsis, according to De Beaugrande (1981), is a repetition of a structure and its content omitting parts of the surface expression ( $p$. 49). Legislators and legal experts tend to interweave their written 
judgments as effectively as they can. That is why they leave out many words and include only those that convey the main idea they want to convey. The intended purpose of ellipsis in legal texts is to achieve brevity and emphasis on the significance of legal eloquence.

\subsubsection{Types of Ellipsis}

Ellipsis occurs only when the parts of the sentence carry the meaning required or presupposed. The elided forms of a sentence also render its meaning clearly, and predictable from its main structure.

1. Ellipsis of the subject: The subject in many sentences found specifically in the legal language of Egyptian Supreme is omitted from its structure leaving a nominative predicate. McCarthy (1991, p.43) refers to this as nominal ellipsis. The Head is often omitted because it can be presupposed via situational or linguistic information provided. Therefore, a nominal group or elliptical Head can be determined from information in the context. This category of ellipsis occurs when the noun and potentially accompanying modifiers are removed from a noun phrase. For example:

and involved a breach of the right of defense

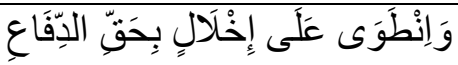

This statement is a predicate to elliptical of the subject noun The ruling / أْحُكْمَمِ This type is a nominal ellipsis because the clause involves the omission of a noun headword which is recoverable from a scrutiny of the situation or linguistic context.

He also reasoned that he was arrested and searched before issuing the order from the public prosecution

Here, the subject noun in Arabic is omitted which is) the defendant الْئنَّهُ because the text provides some information with a presence of evidence i.e., the anaphoric deictic found in the object pronoun him, his . This elliptical nominal group is cohesive as it points anaphorically to 
another nominal group which is presupposed. It can be filled out through the courtroom context and linguistic context. Despite its elliptic structure, nothing takes its place or function, but the evidence is either verbal or circumstantial to support its usage.

\subsubsection{Ellipsis of the Predicate in the legal texts of the Egyptian Supreme Court}

Ellipsis within the verbal group in the legal text of Egyptian Supreme may cause serious problems of ambiguity. Several clauses in legal language can be found without a predicate with only a nominative subject. There are clauses which are found without a predicate. For instance:

the appellant had asked the court to conduct a specific investigation, he has not that-

For this type of ellipsis, there is an ellipsis of the predicate

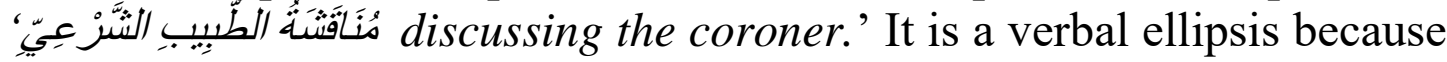
it repeats an element from outside the scope of the text. An ellipsis of the predicate in which the presupposed is understood.

\subsubsection{Ellipsis of the Verb:}

There are many cases in Egyptian legal language where verbs are omitted but the nominative subject remains. Some of these cases can be seen inside the Egyptian legal language as follows:

Statement of the ruling, the fact of the case, and the provision of evidence to prove in a full statement.

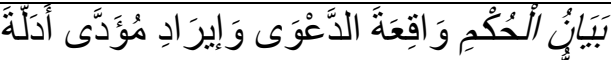

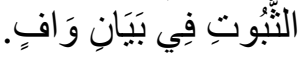

The verb جاء/came is omitted because it came before the nominative

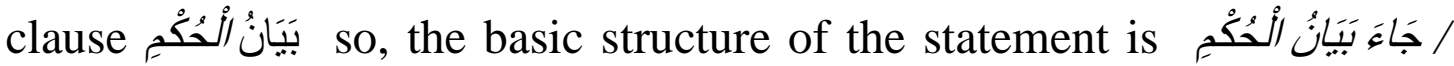
the statement of the ruling came. The meaning is recoverable from the situation or linguistic context. 


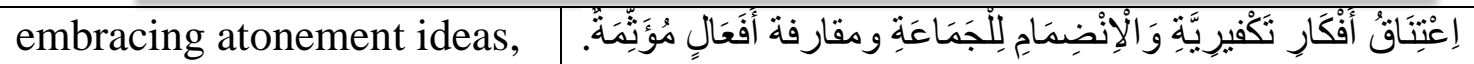
joining the group, and

tracing criminal offences.

The verb إِزَتََبَ / commit is omitted because it came after the

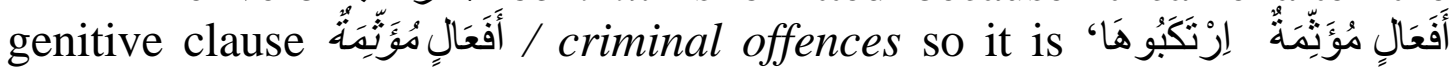
/they committed criminal offences'. The intended meaning is understood in the linguistic or situational context

\subsubsection{Ambiguity of Function Words in the legal texts of the Egyptian Supreme Court}

Function words are those that express a grammatical or structural relationship with other words. They include determiners, conjunctions, prepositions, pronouns, qualifiers, and question words. The omission of quantifier pronouns such as (some, both, most, many, a few, a lot of, any, much, a little, enough, several, none, all) also results in ambiguity of understanding the intended meaning, for example:

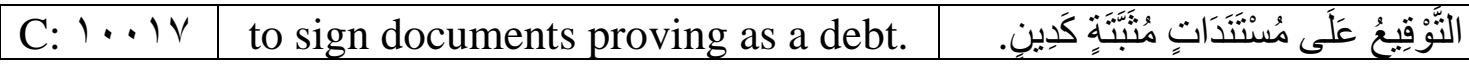

The omission of the quantifier pronoun somel بعض may lead to ambiguity in understanding the intended meaning. There may be more than one document with different signatures denoted by this quantifier. However, there is at least one document (among the documents in a given domain) which the victim signed. The meaning of the statement can be characterized by indeterminacy.

\begin{tabular}{|c|c|c|}
\hline C:17730 & $\begin{array}{l}\text { As long as the perpetrator is } \\
\text { aware of the purpose for } \\
\text { which those crimes are } \\
\text { aimed, his criminal intent is } \\
\text { achieved, and that purpose is } \\
\text { extracted from the content of } \\
\text { those actions as evidence of } \\
\text { the terrorist behavior of the } \\
\text { cult, whether or not the } \\
\text { perpetrator participated in } \\
\text { those acts. }\end{array}$ & 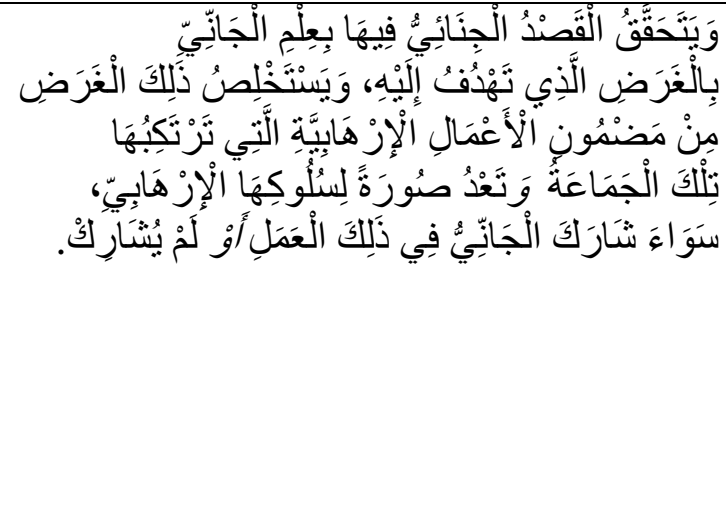 \\
\hline
\end{tabular}


The conjunction word and/g can be read conjunctively or disjunctively? If the proper construction is that and is conjunctive, then a person is to fulfill all precedent terms of the criminal intent mens rea mentioned before being stigmatized as a terrorist. If the proper construction is disjunctive, then the perpetrator who does not participate in that act is not a terrorist. There is nothing in the text which excludes such an interpretation. The peculiar interpretation can be avoided simply by reformatting the text taking care not to specify that 'whether or not the perpetrator participated in that act'. When participants are aware of the cult's main goal, they are immediately labeled as terrorists. Another function word causing ambiguity is or $/ \dot{l}$. When the disjunctive relationship or is intended, however, the meaning may be ambiguous. As a result, there are two related, but distinct types of disjunctions: a. to wait for the lawyer or $b$. to postpone the interrogation. The following statement may be interpreted in one of two ways:

\begin{tabular}{|c|c|c|}
\hline $\begin{array}{l}\text { C: } \\
11229\end{array}$ & $\begin{array}{l}\text { The investigator is not obliged to } \\
\text { wait for the lawyer or postpone } \\
\text { the interrogation until he is } \\
\text { present. }\end{array}$ & 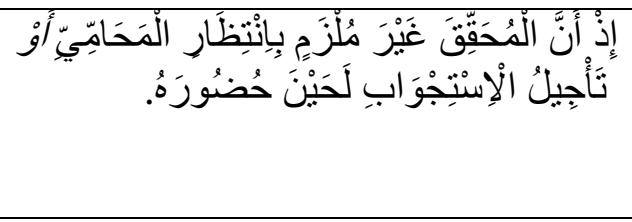 \\
\hline
\end{tabular}

The statement 'The investigator is not obliged to wait for the lawyer', or 'the investigator is not obliged to postpone the interrogation until the lawyer is present' is an example of exclusive disjunction. "To wait for the lawyer" and "to postpone the interrogation until he is present" are both options that can be truthfully specified. This is an instance of inclusive disjunction. Or usually connotes a disjunctive relationship but used conjunctively.

\subsubsection{Surface and Deep Structure in the legal texts of the Egyptian Supreme Court}

A sentence's deep structure, according to Chomsky (1965), is determined by its semantic relations, whereas a sentence's surface structure refers to a mental representation of linguistic expressions that are derived from deep structure via transformational rules (p.16). As a surface or deep structural characteristic, ambiguity occurs when a term that is present in the selection of the underlying 'systemic' options is omitted from the structure. Chomsky (1965) postulates such concepts in 
transformational and generative grammar. This representation identifies the ways a sentence can be analyzed and interpreted to represent meaning through deep structure. There is ambiguity in the written legal language of the Egyptian Supreme court regarding deep and surface structures, as illustrated in the following two statements.

\section{Example (1):}

\begin{tabular}{|c|c|c|}
\hline $\begin{array}{l}\text { (Passive } \\
\text { Voice) }\end{array}$ & $\begin{array}{l}\text { a. The ruling was issued unanimously } \\
\text { by the members of the court }\end{array}$ & 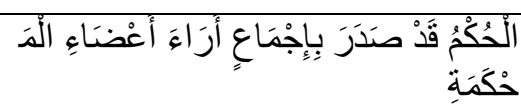 \\
\hline $\begin{array}{l}\text { (Active } \\
\text { Voice) }\end{array}$ & $\begin{array}{l}\text { b. The members of the court issued } \\
\text { the ruling unanimously }\end{array}$ & أَعَرَاءَ \\
\hline
\end{tabular}

The main difference between these two sentences is a difference in their surface structure. Each sentence has a different syntactic form. The first sentence can have a deep structure, like The members of the court sided with the appellant's confession unanimously. In these examples, two different kinds of sentences are shown in these examples: the first is called an active voice, focusing on what the members of the court did, and the second is a passive voice, focusing on the ruling and what happened to it. The distinction between them is a difference in their surface structure, that is, the different syntactic forms they have as individual sentences. The context helps disambiguate the true meaning of the sentence. The context of the Supreme courtroom leads to figure out the subject of the above two sentences. However, this superficial difference in form disguises the fact that the two statements are very closely related, even identical, at some less superficial level. In this underlying level, the basic components (Noun, Verb, and Noun Phrase) of the two sentences are related by their deep structure.

\section{Example (2):}

\begin{tabular}{|c|c|c|}
\hline $\begin{array}{l}\text { (Passive } \\
\text { Voice) }\end{array}$ & $\begin{array}{l}\text { a. The sentence was parted of the } \\
\text { appellant's confession }\end{array}$ & 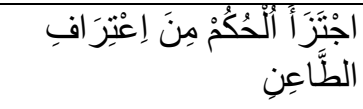 \\
\hline (Active Voice) & $\begin{array}{l}\text { b. The Public Prosecution parted the } \\
\text { ruling from the appellant's confession }\end{array}$ & 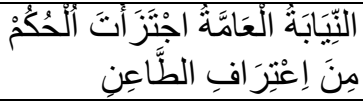 \\
\hline
\end{tabular}


The distinction between these two statements above is a difference in their surface structure. Each sentence has a distinct syntactic form. The first sentence can have deep structure like the Public Prosecution issued the ruling... Two surface different statements are shown in (a) above: the first is called an active voice, focusing on what the Public Prosecution did, and the second is a passive voice, focusing on the ruling and what happened to the

appellant's confession. The distinction between them is a difference in their surface structure, i.e., the different syntactic forms they have as individual sentences. To disambiguate the true meaning of the sentence, context clues are needed. In addition, the context of the Supreme courtroom allows to figure out the subject of the above two sentences. These two propositions can be represented by tree diagrams as follows:

The following diagrams are explained as simple sentences with action verbs. The example (1) contains (Active structure) the members of the court issued the ruling unanimously, 'the subject' the members of the court, is understood as the agent of the action, and 'the object', in the case of the ruling, undergoing the action of issuing, the affected. The following is a tree diagram from (Linda.1993, p.72) as an example to show the syntactic structure of the 'subject' and the 'object' as diagram (1) represents:

Diagram (1):

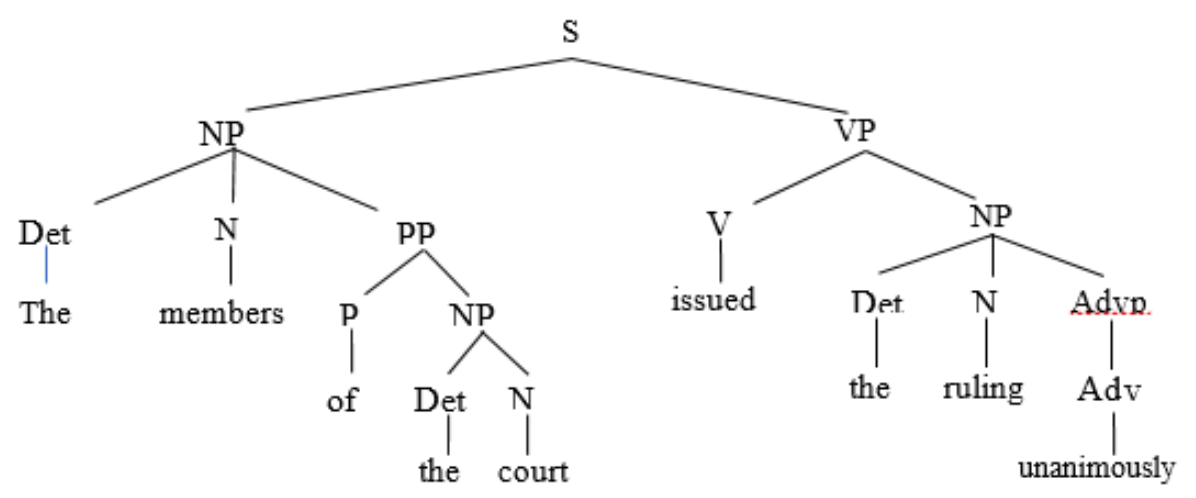

determiner, A

S- mea

DET groups with $\mathrm{N}$ attached to $\mathrm{NP}$, and $\mathrm{VP}$ is comprised of $\mathrm{V}$ and $\mathrm{NP}$, AUX and V make up VP), Adv is attached to VP directly dominated by S. From the diagram tree (1), the subject of a sentence is that NP that is immediately controlled by $\mathrm{S}$; the object is the NP which is immediately under the control of VP. The subject and object are both grammatical 
properties. The main criteria for defining an Adverbial element (unanimously) are whether it gives information pertaining to how. It can be analyzed as a peripheral element of the clause structure, as it is often an optional element and can sometimes be represented in different positions. To construct the passive 'structure' from this 'Active sentence' above, there are four main differentiations as (Radford et al. 1999. p333) pinpoint. One is that passive sentences generally contain the form of the auxiliary 'be', another is the verb in passive sentences is in' $-\mathrm{n}$ past participle form', the third is passive sentences may include a 'by-phrase' which contains the subject in the active sentences and the last is the position of the agent and the affected. Features of the passive sentence of example (1) can be shown as follows in diagram (2):

-The ruling was issued by the members of the court unanimously.

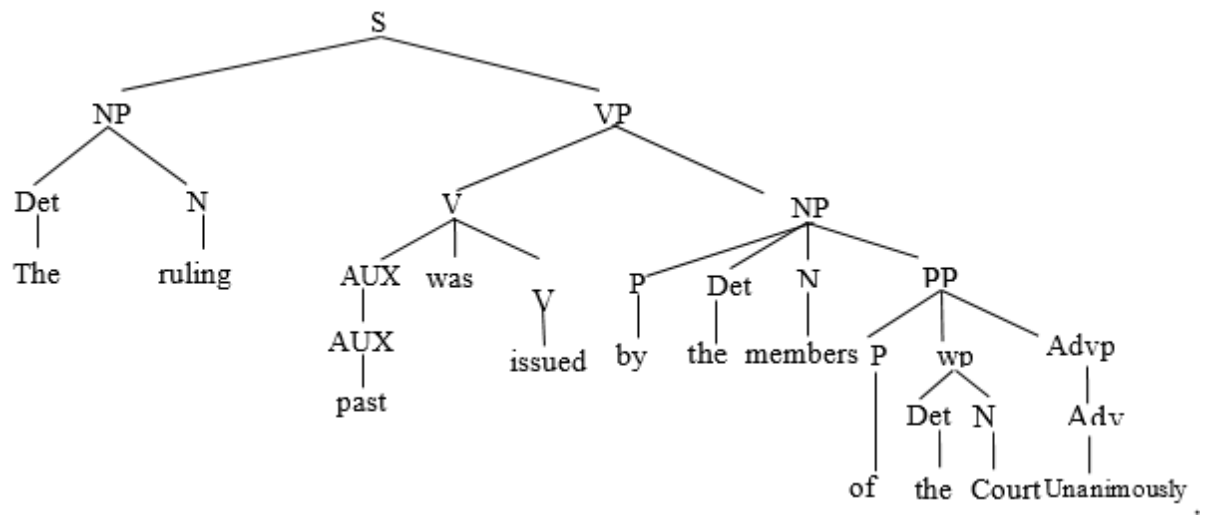

The passive sentences are used to emphasize the object in the active sentences.

Diagram (2):

Based on the 'Active sentence', the following diagram (3) below illustrates how to construct the passive structure. Based on the appellant's confession, the Public Prosecution divided the ruling into four main points. As an example, passive sentences use the auxiliary "be" was, passive sentences use the "past participle form parted, and passive sentences include 'by-phrases' that include the main subject of active sentences (Public Prosecutions is an example), and the final case is the position of the agent and the affected the appellant's confession. 
Features of the passive sentence of example (2) can be shown as follows in diagram (4):

-The sentence was parted of the appellant's confession (by the public prosecution).

-This passive construction emphasizes 'the object' in the active sentences.

Diagram (3):

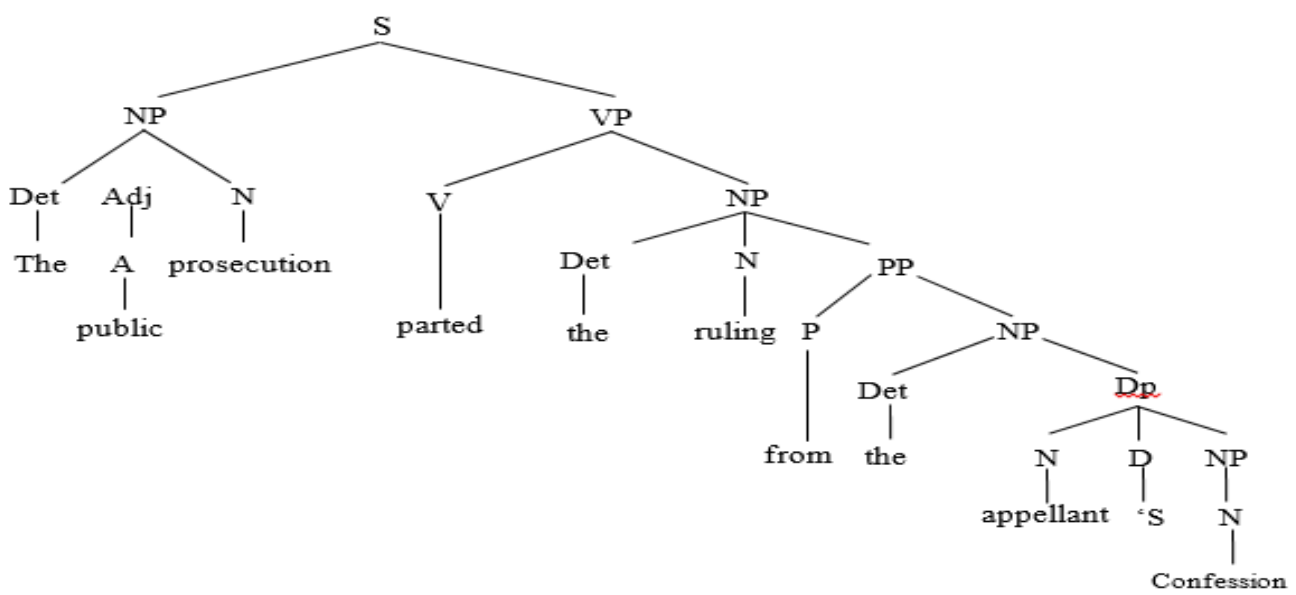

Diagram (4):

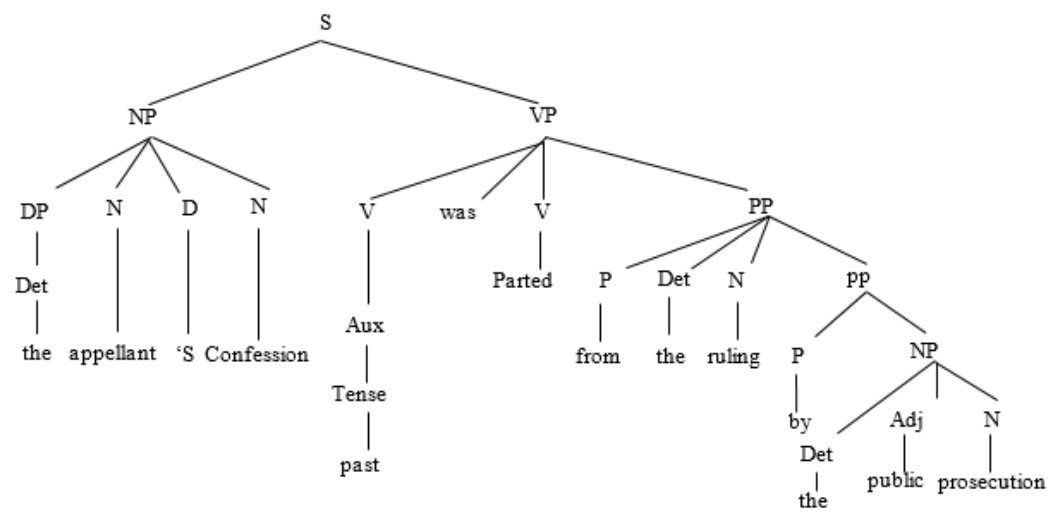

It can be observed that the deep structure in these diagrams above is an abstract representation identifying the ways a sentence can be analyzed and interpreted. This is to disambiguate the intended meaning and relations of subject and object. In addition, it delineates all lexical insertions and semantic interpretations at the deep structure. 


\subsubsection{Ambiguity with pronouns in the legal texts of the Egyptian Supreme Court}

In a sentence, a pronoun replaces a noun by specifying the function or role of an antecedent word to avoid repeated nouns. (Halliday and Hasan, 1976, p.44). Ambiguity may arise when there are two antecedents or references. In this case ambiguity may give two interpretations to one single noun or sentence, as for example:

\begin{tabular}{|c|c|c|}
\hline 10017 & $\begin{array}{l}\text { the latter took trust receipts on the accused } \\
\text { and claimed him payment, but the latter did } \\
\text { not fulfill it, so he thought quietly }\end{array}$ & 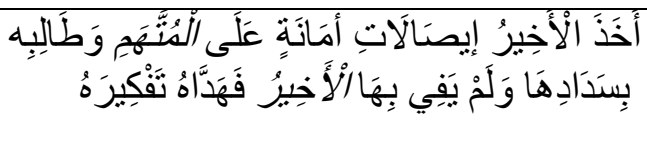 \\
\hline
\end{tabular}

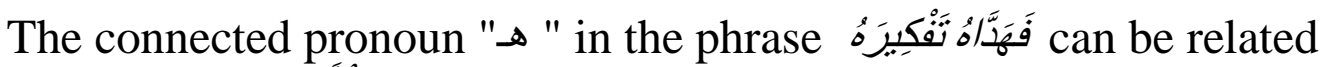
to either the latter/ الْ اخِبِيرُ for being furious about the way he has been

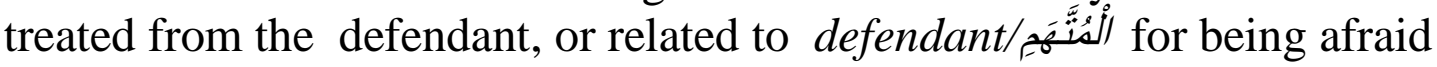
of his crime.

\begin{tabular}{|c|c|c|}
\hline 0017 & $\begin{array}{l}\text { his interrogation before the Public } \\
\text { Prosecution ... by sending in the request of } \\
\text { one of the lawyers from the syndicate to } \\
\text { attend the questioning of the appellant, but } \\
\text { it was unable to do so because of the } \\
\text { closure of the syndicate. }\end{array}$ & 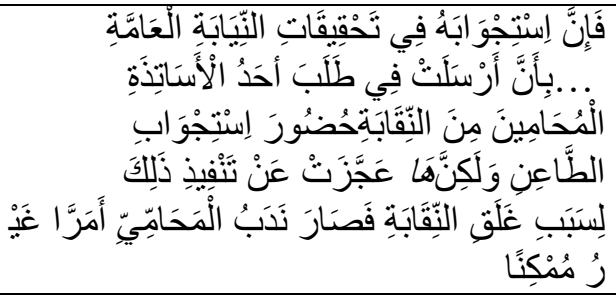 \\
\hline
\end{tabular}

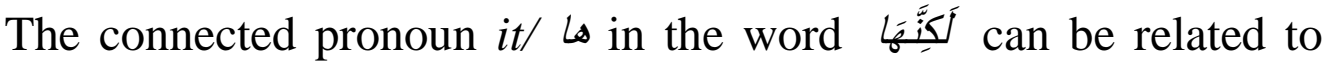
either the Public Prosecution/ النيابة العامة for being the principal authority, or related to the syndicate/النقابة/lawyers for being the laffiliated to its authority.

\subsubsection{Relative Clause Ambiguity}

This kind of ambiguity occurs when it is unclear, to what part of the preceding main clause a relative clause is referring to. For example:

\begin{tabular}{|c|c|c|}
\hline $\mathrm{C}: 1 \ldots \mathrm{IV}$ & $\begin{array}{l}\text { That confession is } \\
\text { innocent of what it taints } \\
\text { to refute the response that } \\
\text { the appellant's defense has } \\
\text { put to the invalidity of that } \\
\text { confession. }\end{array}$ & 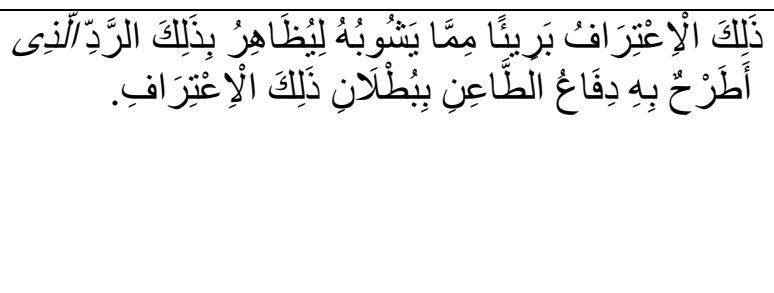 \\
\hline
\end{tabular}




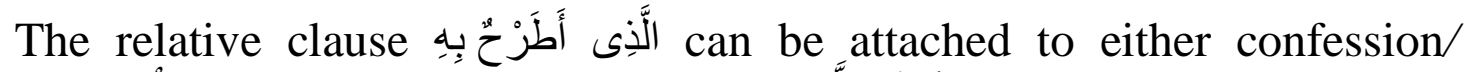

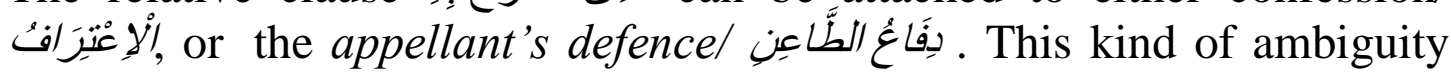
occurs due to the fact that the relative clause's grammatical properties are determined by the associated noun. Another example as follows:

\begin{tabular}{|c|c|c|}
\hline$C: 1 \ldots 1 v$ & $\begin{array}{l}\text { the ruling dealt with the } \\
\text { defendant's objection that was } \\
\text { raised and responded to refute it. }\end{array}$ & 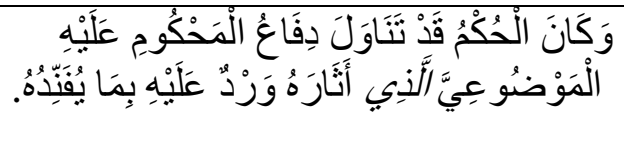 \\
\hline
\end{tabular}

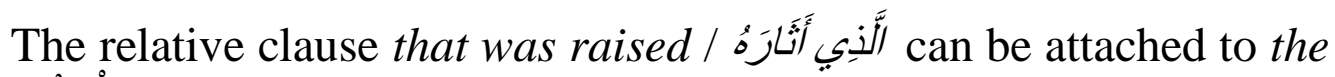
ruling/الْحُكْمُ . The relative clause's grammatical properties are determined by the associated noun. The relative clause attachment is unambiguous because it may be attached to a noun following it defendant's objection

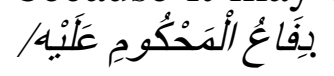

\subsubsection{Coordination Ambiguity in the legal texts of the Egyptian Supreme Court}

Coordination ambiguity is a kind of structural ambiguity that generally arises if a coordinated structure (e.g., CNP or CVP) is used in combination with a modifier. A typical coordination and modifier combination consists of a coordinated noun phrase along with an adjective or adjective phrase.

\begin{tabular}{|c|c|c|}
\hline$C: 11$ YYq & $\begin{array}{l}\text { It is purely an objective } \\
\text { controversy concerning the } \\
\text { authority of the trial court in } \\
\text { assessing the evidence and } \\
\text { determining its belief on the } \\
\text { basis of it that the appellants } \\
\text { bring to the Court of } \\
\text { Supreme. }\end{array}$ & 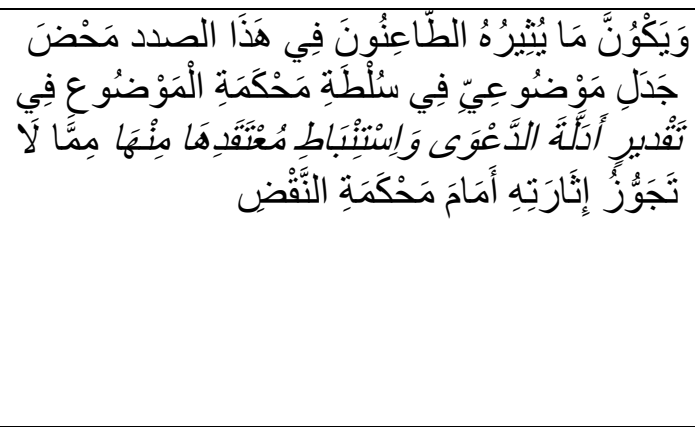 \\
\hline
\end{tabular}

Coordination Ambiguity like assessing the evidence and

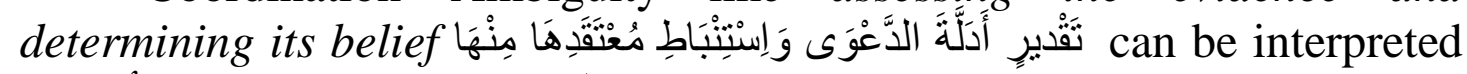

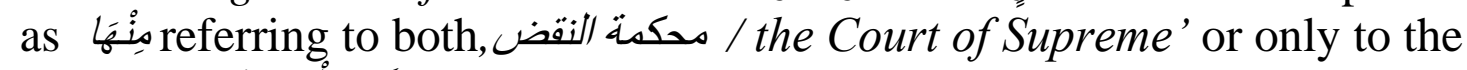

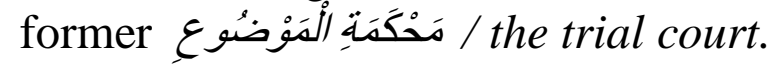




\subsubsection{Adjective Reference Ambiguity in the legal texts of the Egyptian Supreme Court}

Whenever an adjective occurs it should have a reference which it modifies. It always follows the noun in Arabic to modify either the subject or the object in a sentence. Ambiguity arises when more than one adjective is being mentioned in a sentence with only one antecedent. In this case, either one adjective is being related to the antecedent or all adjectives are so. For example:

\begin{tabular}{|c|c|c|}
\hline $\mathrm{C}: 11$ rYq & $\begin{array}{l}\text { Furthermore, the court } \\
\text { objected to the appellant's } \\
\text { demur - in this regard - and } \\
\text { explained it in a justifiable and } \\
\text { adequate manner. }\end{array}$ & 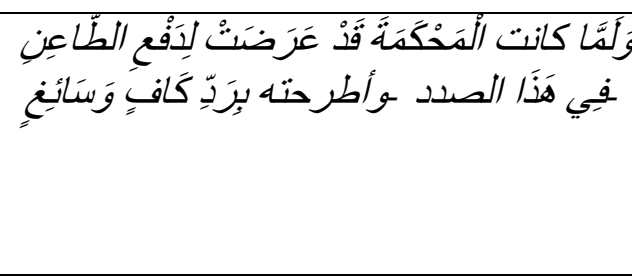 \\
\hline
\end{tabular}

The adjective adequate / سَائغِ can be related to دَفْعِ الطَّاعِنِ / the appellant, or related to الرد س response an adequate response" in this way, adequate/ سائغة would be either adequate for both of the two antecedent nouns.

\begin{tabular}{|c|c|c|}
\hline$C: 11$ YYq & $\begin{array}{l}\text { as well as the crime of acquiring a } \\
\text { white weapon without justification and } \\
\text { the theft of which the convicted person } \\
\text { was condemned to death and presented } \\
\text { it with reasonable evidence. }\end{array}$ & 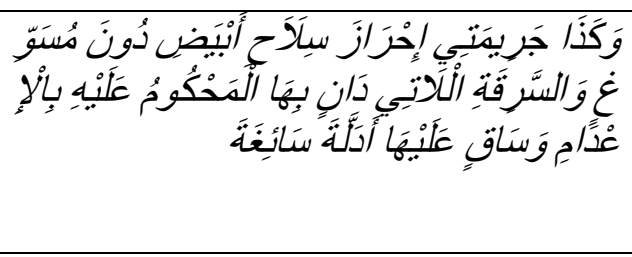 \\
\hline
\end{tabular}

The adjective adequate/ سَائغَنَ can be related to all what have

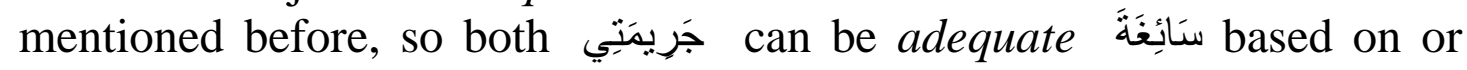
using good judgment and therefore fair and practical, or related to either

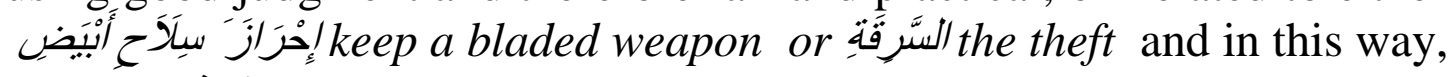
adequate سائغة is either for the two crimes or the theft. 
Elieba, Fakhry Muhammad Al-Sayed. (BIJHS) 2020, 2 (2): 114 - 164

\begin{tabular}{|c|c|c|}
\hline IVVT. & $\begin{array}{l}\text { An unheated rifle, } \\
\text { explosives and the } \\
\text { devices used in an } \\
\text { explosion, as well as } \\
\text { possession } \\
\text { acquisition } \\
\text { explosives. }\end{array}$ & 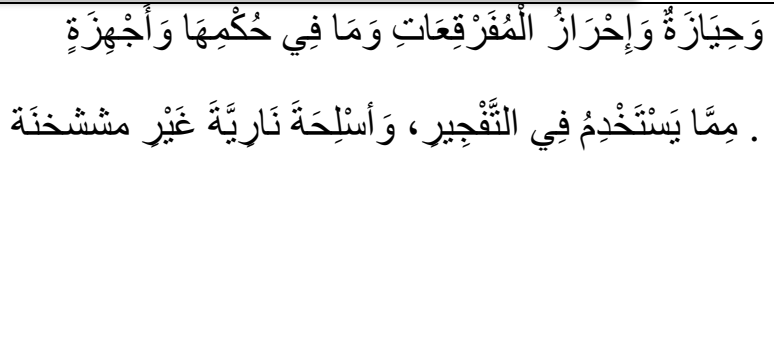 \\
\hline
\end{tabular}

The adjective unheated/غَيْرِ مششخَنَّ can be related to all what have mentioned before, or this adjective can be related only to rifles or fire

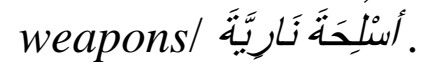




\section{Conclusion}

Three legal texts of the Egyptian Supreme Court are examined in this paper for their textuality and ambiguity. The language of these legal texts is identified by a particular selection and use of grammar, vocabulary, structure and function. Characteristics that underlie this type of textuality involve a complex set of features such as singularity and straightforwardness. Therefore, the criteria of textuality (cohesion, coherence, intentionality, acceptability, informativity, situationality, and intertextuality) are introduced as the constitutive principles defining textual communication of these legal texts. Basically, the concept of legal textuality and the standards that it implies produces the principle of the textual model. This model deals with the process of interpretation in order to fully comprehend the meaning and intent of this written legal language. This study includes particular choices of grammatical and lexical forensic terms to simplify the understanding of obligations and responsibilities for action. The three forensic cases are analyzed grammatically and compared. In the study, the proportion of differences between grammatical word classifications for the three cases is revealed. All five words appear in the three legal texts together with other characteristic syntactic and lexical distinctive features. A comparison with ordinary language reveals that Supreme Court lexical items have different frequencies. In terms of lexical items, the most frequent items were defendant/ appeal/ homicide/ crime/ evidence, terrorist, appeal/murder/ objection/ execution/ judgment/ law/ commit. The majority of frequent lexical words are unusually grammatically complex and overlexicalized. Almost all of the words listed are nouns. They refer to the individuals involved in the court judgment as well as to the cause itself as a request by the defendants. 
The thematic structure of the three criminal cases reveal the five syntactic forms associated with 'given' information like (1) Lexical units which are mentioned for the second time, (2) Lexical units which are presented as being within the semantic field of a previously mentioned lexical unit, (3) Pronominals used anaphorically following a full lexical form in the preceding sentence,(4) Pronominals used exophorically where the referent is present, and finally, (5) Pro-forms Moreover, this paper examines the phenomenon of legal ambiguity in three written texts in the Supreme court. This reveals that this phenomenon has more than one meaning. There is the familiar, natural or general meaning, which deals with the way language is used and understood by people in general. Hence, Legal ambiguity occurs where there is absence of clarity or when uncertainty exists in the application of a term. The other meaning is the restricted meaning which is confined to certain lexical and grammatical features that are part of the common language, regardless of anyone's usage or understanding.

Therefore, legal texts are one of the sources for ambiguity occurring as a result of either deficiency in the language and the restricted linguistic competences of those who are charged with preparing the written legal texts, or in the complex drafting style of written legal texts which is unclear and difficult to understand. The same thing can occur in the wording when a legal term refers to one meaning and then to another. In the study, two types of legal ambiguity were identified in written legal texts. The first is lexical or semantic type which arises when a word has more than one meaning. The structure type which arises when the role of a word in a sentence is unclear. Through the examination of about twenty legal terms, the study also investigates the lexical and structural ambiguity of legal texts of the Egyptian Supreme Court. Polysemy turns out to be one of the main factors of lexical ambiguity. However, structural ambiguity of legal texts appears to arise from nouns, verbs, and adjectives in addition to other factors, as examined above. 
To disambiguate the intended meaning, the study asserts that the meaning of a word or a sentence is the appropriate context, whether linguistic or contextual. Linguistic context refers to syntax, which restricts the construction of sentences, so this type can account for structural ambiguity. Whereas situational context refers to semantic ambiguities or lexical associations, so this type can account for lexical ambiguity. The relationship between lexical and structural ambiguity presupposes their identification. By identifying them, it is possible to resolve ambiguity simply by contextual or textual analysis. This relation can be clearly identified if its source is well understood. That is why the phenomena generating ambiguities can be resolved by specific mechanisms such as identification of context, syntactic construction and lexical relations. 


\section{Recommendations}

Legal language is more of a word order language, meaning the arrangement of words is very significant. Changing the word order changes the meaning. As a result, when drafting the legal text, it is important to consider the exercise of prudence in terms of drafting the legal text. Written legal language is recommended to be short sentences, active voice, action verbs, imperative mood, simple words and avoid redundancies as far as it can. 


\section{Endnotes}

(1) Associated Press. "Think Corning Girl Wrote Ransom Note" https://www.powerthesaurus.org/crime/synonyms.

https://en.wikipedia.org/wiki/Forensic_linguistics\#cite_note-7

(2) Okawara, Mami Hiraike (2018). The Interdisciplinary Study of Law and Language: Forensic Linguistics in Japan. In D. G. Hebert (Ed.), International Perspectives on Translation, Education and Innovation in Japanese and Korean Societies. Cham: Springer, p.197-206. https://en.wikipedia.org/wiki/Forensic_linguistics\#cite_note-7

(3) https://en.wikipedia.org/wiki/Forensic_linguistics\#cite_note-7

4 Dr. Abdul Qadir Al-Sheikhly. The art of legal drafting. Legislation, jurisprudence and jurisdiction. Library of Culture and Distribution House. Oman.

(5) Nordquist, R. Pro-Form in Grammar. ThoughtCo, Feb. 11, 2020, thoughtco.com/pro-form-grammar-1691537. 


\section{References}

1) Alcaraz Varó, E., \& Hughes, B. (2002). Legal translation explained. Manchester: St. Jerome Publishing. p.5

2) Ali, J, M. (2020) Forensic Linguistics: A Study in criminal Speech Acts. Beni Suef University, Egypt.

3) Berk-Seligson, S. (2017). The bilingual courtroom: Court interpreters in the judicial process. University of Chicago Press.

4) Brown, G., \& Yule, G. (1983). Discourse analysis. Cambridge: Cambridge University Press.

5) Chomsky, N. (1965). Aspects of the theory of syntax. Cambridge. Multilingual Matters: MIT Press.

6) Cornu, G. (1990). Linguistique juridique, coll.«. Domat droit privé», Paris, éd.Montchrestien.

7) Coulthard, M., Johnson, A., \& Wright, D. (2016). An introduction to forensic linguistics: Language in evidence. Routledge.

8) Cushing, S. (1994). Fatal words. Chicago: U. of Chicago Press.Forensic Linguistics.Vol. 3, No. 1.

9) Crystal, D. (1988). The English Language. Harmondsworth: Penguin.

10) Crystal, D. (2008). A dictionary of linguistics and phonetics. John Wiley \& Sons. 
11) Crystal, D., \& Davy, D. (1986). Investigating English style. Routledge.

12) De Beaugrande, R. A., \& Dressler, W. U. (1981). Introduction to text linguistics (Vol. 1). London: longman.

13) Empson, W. (1949). Seven types of ambiguity. Chatto and Windus: London.

14) Fairclough, N. (1992). Discourse and text: Linguistic and intertextual analysis within discourse analysis. Discourse \& society, 3(2), 193-217.

15) Falzini, W. (2008). The Ransom notes: An analysis of their content and signature. Pridobljeno, 24, 2014.

16) Gibbons, J. (1994). Language and the law. London: Longmans.

17) Gibbons, J. (2004). Language in the law/John Gibbons [et al]. New Delhi, Orient Longman Private Limited.

18) Halliday, M. A. K., \& Hasan, R. (1976). Cohesion in english. London : Longman Group Ltd.

19) Hardaker, C. (2015). The ethics of online aggression: Where does "virtual" end, and "reality" begin? BAAL Conference on The Ethics of Online Research Methods. Cardiff.

20) Hurford, J. R., Heasley, B., \& Smith, M. B. 
(2007). Semantics: a coursebook. Cambridge university press.

21) McCarthy, M. (1991). Discourse analysis for language teachers (Vol. 62). Cambridge: Cambridge University Press.

22) Mellinkoff, D. (1963). The Language of the Law. Boston, MA: Little, Brown \& Co.

23) Olsson, J. (2004). An introduction to language crime and the law. London: Continuum International Publishing Group.

24) Olsson, J. (2008) Forensic linguistics: Second Edition. Continuum International Publishing Group.

25) Radford, A., Atkinson, M., Britain, D., Clahsen, H., \& Spencer, A. (2009). Linguistics: an introduction. Cambridge University Press.

26) Rieber, R. W., \& Stewart, W. A. (1990). Language scientist as expert in the legal setting. New York: Academy of Sciences.

27) Riggs, F. W. (1989). Descriptive terminology. Its Relevance for the social sciences, in Nedobity, W.(ed.) Terminologies for the Eighties, Info term Series 7, Munich, K. G. Saur, pp. 144-160.

28) Sabra, A. M. M. (1995). Translation of Contracts. The American University of Cairo. 
29) Sabra, M. M. (2007). Origins of legal drafting in Arabic and English.

Languages-learning library.

30) Salih, A. H. (2015). Factors of Structural Ambiguity in English and Arabic: A Contrastive Study.

31) Santos, M. (2004). A pragmalinguistic analysis of courtroom questions in a multilingual context. Retrieved from

http://www.tesionline.it/consult/pdfpublicview.asp?url/PD

F/18309/18309p.pdf (accessed 9 April 2020).

32) Shuy, R. W. (1998). The language of confession, interrogation, and deception (Vol. 2). Sage.

33) Shuy, R. W. (2001). 'Discourse Analysis in the Legal Context' in Deborah Schiffrin,

34) Deborah Tannen, and Heidi E. Hamilton. The Handbook of Discourse Analysis.

35) Solan, L. M. (2010). The language of judges. University of Chicago Press.

36) Stockwell, R. P., Elliott, D. E., \& Bean, M. C. (1977). Workbook in syntactic theory and analysis. Prentice-Hall.

37) Stygall, G. (1994). Trial language. Philadelphia: John Benjamins.1-238. 
38) Svartvik, J. (1968). The Evans statements: A case for forensic linguistics. Gothenburg Studies in English, 1-29. 39) Tiersma, P. (1995). The language of silence. Rutgers $L$. Rev., 48, 1 .

40) Tiersma, P. (1999). Legal language. University of Chicago Press.

41) Tiersma, P. (2001). Textualising the law, forensic linguistics. University of Chicago Press.

42) Tuggy, D. (1993). Schematic network: Ambiguity, polysemy, and vagueness. Dirk Geeraerts (toim.). Cognitive linguistics: Basic readings, 167-184.

43) Zakariyah, L. (2013). Textuality as a linguistic mechanism for codifiying legal maxims in Islamic criminal law. American Journal of Islamic Social Sciences, 30(1), 22-47. 
BSU International Journal of Humanities and social science 